\title{
APLICAÇÃO PRUDENCIAL DOS ESQUEMAS NORMATIVOS
}

\author{
Antonio Carlos de Campos Pedroso \\ Professor Associado do Departamento de Filosofia e Teoria Geral do \\ Direito da Faculdade de Direito da Universidade de São Paulo
}

\begin{abstract}
Resumo:
O presente estudo pretende destacar a função da prudência na aplicação dos esquemas normativos. Estes contêm preceitos típicos para a generalidade das situações convivenciais. Mas, os casos concretos apresentam circunstâncias relevantes que precisam ser consideradas. A via para a resolução do dilema norma-caso está na construção prudencial das decisões. Assim, pode o juiz, sem descurar da teleologia imanente ao sistema, traduzir, para o caso concreto, através de procedimentos hermenêuticos estudados ao longo deste trabalho, as exigências axiológicas que a hipótese reclama.
\end{abstract}

Abstract:

The present study intends to detach the function of the prudence in the application of the normative outlines. These count typical precepts for the generality of the acquaintanceship situations. But, the concrete cases present important circunstances that need to be considered. The way for the resolution of the norm-case dilemma is in the prudential construction of the decisions. Like this, the judge can, without forget about the immanent theology to the system, to translate, for the concrete case, through hermeneutics procedures studied along this work, the axiological demands that the hypothesis complains.

Unitermos: prudência jurídica; processo de tipificação; processo de individualização; dilema norma-caso.

Sumário:

1. Introdução. A atividade cognoscitiva do Direito. A prudência jurídica.

2. O processo de tipificação. A articulação das normas jurídicas. Normas genéricas e seus caracteres.

3. O processo de individualização. O dilema norma-caso. Tipologia das soluções. A aplicação prudencial do Direito.

4. Resolução do dilema norma-caso. Análise dos processos hermenêuticos.

5. Resolução do dilema norma-caso. Desenvolvimento do Direito intra-legem e supra-legem. 
6. Aplicação prudencial do Direito. Dimensão criadora da prudência. O silogismo prudencial. Prudência e "direito de situação"

7. Conclusões.

1. Introdução. A atividade cognoscitiva do Direito. A prudência jurídica.

Consiste a interpretação numa pesquisa capaz de revelar o sentido e o alcance dos esquemas normativos, a fim de que estes, devidamente aplicados aos fatos da vida convivencial, projetem o justo concreto.

Isto significa que à interpretação cabe resolver o dilema norma-caso, uma vez que a norma se apresenta revestida de abstração e generalidade e o caso, de individualidade e concreção. As normas jurídicas são genéricas e abstratas, constituindo o paradigma de que se valem os intérpretes para a busca do justo concreto. O objetivo da interpretação é, nesta ordem de idéias, a conversão das normas genéricas nas normas individualizadas. A estas cabe dimensionar, prudentemente, o direito concreto. Há uma tensão entre a generalidade da norma e a particularidade do caso concreto. É uma dicotomia decorrente de critérios: o tipificador, inerente aos preceitos do direito normativo e o individualizador próprio da casuística. O salto a ser dado entre o abstrato e o concreto é o ponto central da problemática hermenêutica.

Realmente, a Ciência do Direito é, por natureza, de ordem prática. O contexto do caso concreto é seu objetivo último. Neste sentido a lição de Arthur $\mathrm{F}$ Utz, in verbis: "desejamos simplesmente insistir sobre o fato de que o direito não se realiza senão na relação interpessoal concreta. A análise da ordem real deverá então evidenciar os preceitos segundo os quais o caso concreto e particular está em condições de ser determinado juridicamente".'

O processo cognoscitivo do Direito não-envolve, apenas, como pretende Kelsen, uma operação lógica, mas, deve traduzir, através de adequados juízos prudenciais, o sentido e o alcance dos preceitos normativos. A interpretação deve traduzir o preceito ético diretivo do caso concreto. O intérprete não pode ser guiado, exclusivamente, por fórmulas, já que estas só têm sentido dentro do quadro geral dos valores de convivência sistematicamente equacionados no contexto

1. Utz, Arthur. Éthique Sociale, Philosophie du Droit, tome II, trad. Vicent Kleiber, Suisse, Ed. Universitaires de Fribourg, 1967, pp. 20-21. 
normativo. Aristóteles, na Ética a Nicômaco afírmava ser viciosa a aplicação mecânica da lei.

Por isso, entendemos que a interpretação não se resume apenas numa atividade cognoscitiva racional, mas abrange, também, uma atividade volitiva e decisória, exigindo esta a valoração de possíveis soluções, aptas a traduzir o justo concreto. Por outras palavras: a interpretação é um ato de construção prudencial.

A prudência permite a solução do impasse porque, de um lado; é vinculada e dependente da teleologia imanente ao sistema, e, por outro, adaptável ao caso concreto, revestido de contingência. Só ela possibilita a aplicação eqüitativa do Direito.

Releva salientar, a título de ilustração, que a sentença judicial bem evidencia semelhante propósito. Ela é um exemplo típico de aplicação prudencial do Direito. Sua elaboração exige, como alicerce, valorações que vêm do juízo prudencial.

A sentença é um ato do conhecimento prático. A virtude do intelecto rático possibilita a aplicação dos princípios gerais, de ordem normativa, aos casos zoncretos, apesar de os primeiros se revestirem de generalidade (essência) e os segundos, de singularidade (existência). Só a prudência permite a aplicação eqüitativa do Direito.

A sentença é, assim, um ato do conhecimento prático em que intervém o juízo prudencial. Mas, não é só: o fulcro da sentença é a valoração. Se a descrição fenomenológica da experiência jurídica revela estar o Direito ligado a uma exigência de Justiça, então, esta exigência deve estar na norma genérica da lei e na norma individualizada da sentença. Se o legislador não deve elaborar a lei sem levar em conta determinados objetivos contidos na idéia do Direito (o justo), o mesmo ocorre com o juiz, que não deve formular a sentença sem se inspirar nos valores de convivência que se inserem no sistema normativo. A sentença possui, assim, essência ética, regulando a ação mais de perto do que a norma.

Assim sendo, a sentença não pode ser reduzida a mero esquema lógico. O mesmo acontece com as demais normas individualizadas (o negócio jurídico, o ato administrativo especial e o tratado contrato) que traduzem valorações contida na teleologia do sistema.

A interpretação, como pretendemos demonstrar no presente trabalho, é a pesquisa, no contexto normativo de cada instituição, do princípio axiológico que a anima, a fim de que, esse mesmo princípio, possibilite a compreensão do preceito 
aplicável à espécie, levando-se em conta as notas distintivas da situação conflitual. A arte do Direito é a arte de regular o justo entre pessoas determinadas. O sentido lógico não pode ser desconectado do sentido axiológico. O sentido lógico é apenas o processo, o instrumento que viabiliza a decisão justa para o caso concreto.

A interpretação é, assim, um ato de valoração decorrente de um juizo prudencial. Só ela permite a determinação do preceito aplicável à espécie em harmonia com a tipologia do sistema e sem descurar dos fatores contingentes da situação convivencial. O preceito normativo pretende ser lógico e justo.

Bem adverte o teólogo moralista Bernhard Häring, cuja linguagem, destinada à decisão ética, coincide com a do jurista que repele a concepção dedutivista: "O legalista se interessa somente por fórmulas áridas, não pela vida ou pelas pessoas. Tendo perdido o contato com o homem da vida real, ele também perde o contato com os valores e com as fontes da vida e da verdade. Servem-lhe de guia principios vazios ou principalmente fórmulas, e ele não considera como e porque tais principios foram formulados e quais os valores humanos que inicialmente os justificavam" ${ }^{2}$

2. O processo de tipificação. A articulação das normas jurídicas. Normas genéricas e suas notas características.

A tipificação é o processo de que se vale o legislador para a configuração dos comportamentos nas normas jurídicas. Resulta do conceitualismo e da abstração, como princípios diretivos da elaboração do Direito.

Com efeito, o legislador, pela própria natureza de suas funções, procura configurar as notas essenciais de que se revestem as relações sociais em construções típicas. Tais elementos passam a constituir a estrutura do tipo. A lei só apreende o universal. No equacionamento dos fatores constitutivos da licitude ou da ilicitude, o legislador apenas retém o essencial à formação do tipo, desprezando as notas individuais da conduta convivencial em sua realização concreta. O real é ordenado em esquemas normativos, os quais se referem à essência de uma série de fatos da vida convivencial.

Este é o processo metodológico do conceitualismo. É o tratamento esquemático generalizador referido por Heinrich Henkel. O legislador só se

2. Häring, Bernhardt Moral Personalista, trad. Márcio Fabri dos Santos, São Paulo, Paulinas, 1974, p. 167. 
preocupa com o formação jurídica de tipos. ${ }^{3}$ Em Direito Penal, por exemplo, é o instrumento conceitual para a descrição do injusto. É a descrição da conduta proibida pela norma, como explica Enrique Bacigalupo. ${ }^{4}$

O Direito é uma ciência tipológica. Assim se expressa Miguel Reale: "todo conhecimento jurídico implica certa tipologia. A ciência não pode prescindir de categorias, tipos, espécies, classes ou famílias adequadas a uma região da realidade. São esquemas ideais ou modelos que prefiguram normativamente a conduta possivel, reputando-a lícita ou ilícita" ${ }^{5}$

Por isso, a contemplação jurídica é genérica.

Referido processo de abstração é necessário à Ciência do Direito. Inexistindo ciência do individual e contingente, segue-se que o conceito implica exclusão de toda referência às circunstâncias específicas da conduta humana. A Ciência do Direito visa, no contingente e individual (conduta em interferência intersubjetiva), aquilo que é universal e necessário, a saber, os tipos. As situações de fato abstratamente consideradas se expressam em normas genéricas.

Estas assim se definem: normas genéricas e abstratas são as que se dirigem a um número indefinido de pessoas, a todos aqueles que se enquadram na classe designada pela hipótese normativa, e regulam ações-tipo, isto é, as que são universais relativamente às ações prescritas.

Constitui nosso objetivo demonstrar que o ato interpretativo é, em última análise, a conversão das normas genéricas, assim conceituadas, em normas individualizadas, isto é, em normas que se dirigem a destinatários identificados e regulam ações concretas. Referida passagem exige considerações de ordem lógica e axiológica, envolvendo a aplicação prudencial do Direito.

Realmente, a construção gradualística do ordenamento jurídico permite divisar, como parte integrante do sistema e com caráter eminentemente normativo, as normas individualizadas. O sistema jurídico é composto de normas genéricas, abrangendo estas as normas ordinárias e regulamentares, e de normas individualizadas, nestas se incluindo os negócios jurídicos, os atos administrativos especiais, as sentenças judiciais e os tratados-contratos. Pois bem, as normas

3. Henkel, Heinrich. Introducción a la Filosofia del Derecho, trad. Enrique Gimbernat Ordeig, Madri, Taurus, 1968, pp. 576-577.

4. Bacigalupo, Enrique. Principios de Derecho Penal. Parte General, Madri, Akal Ed., 1990, pp. 99-102.

5. Reale, Miguel. Filosofia do Direito, $9^{a}$ ed., São Paulo, Saraiva, pp. 56-59. 
genéricas constituem os paradigmas que traçam as diretrizes para as individualizadas. Estas, por sua vez, dimensionam os direitos subjetivos e os deveres jurídicos previstos, em caráter prospectivo, nas normas genéricas.

No sistema hierárquico e escalonado, as normas jurídicas estão distribuídas em planos, havendo, na passagem de um a outro, a possibilidade de complementação normativa. Inegável, assim, a ocorrência de uma atividade criadora e sucessiva de normas, que se iniciam pelas constitucionais, se prolongam nas ordinárias e regulamentares e culminam nas individualizadas.

As normas genéricas traduzem os valores de convivência social necessários à existência e aprimoramento da cooperação social (bem comum), sendo esta indispensável à realização do ser humano (bem pessoal). A norma jurídica é, assim, o instrumento de que se vale o legislador para a disciplina das relações de convivência, segundo valores que ele consagrar.

Contudo, somente as normas individualizadas atribuem pleno sentido a esse complexo normativo. Elas regulam o justo concreto. A arte do Direito é a arte de regular o justo concreto, atribuindo aos participantes da relação jurídica o jus debitum relativos a uma situação de convivência. As concretizações devem ser alcançadas segundo cânones hermenêuticos consagrados na doutrina. A aplicação do Direito, diz Eduardo Garcia Maynez é "o processo mediante o qual uma situação juridica abstrata transforma-se em concreta, e uma norma genérica se individualiza". 6

Semelhante aplicação é de ordem lógica e axiológica, envolvendo valorações que se realizam, segundo pensamos, através do juízo prudencial.

3. O processo de individualização. O dilema norma-caso. Tipologia das soluções. A aplicação prudencial do Direito.

O critério tipicador, como vimos, é o critério do legislador. Este, ao elaborar a norma jurídica, tem que ordenar a matéria do bem comum. A qualificação típica tem índole prospectiva, sendo destinada a reger fatos convivenciais futuros.

Diferente é o critério do juiz. Este deve solucionar um conflito de interesses, isto é, um caso concreto. O juiz disciplina mais de perto o fato. 
A contemplação jurídica atinge, agora, caracteres individualizantes. A "individualidade juridicamente relevante" a que se refere Heinrich Henkel, permite o tratamento eqüitativo que promana da decisão. A própria tipicação exige a individualização à aplicação do Direito.

Aqui a Lógica Formal não pode ter o mesmo papel, já que não se trata de qualificação abstrata, nem de mera dedução silogística, mas, sim, de uma compreensão do sentido de valor imanente ao caso.

A Justiça do caso concreto, a saber, a eqüidade, decorre de um processo de construção prudencial, dentro dos parâmetros do sistema, mas, segundo critérios que devem atender às exigências que decorrem da "natureza da coisa". Como se expressa Helmut Coing: "o conhecimento das conexões ontológicas da natureza humana e da legalidade interna dos processos sociais é imprescindivel à constituição do direito justo" E mais: "decidir um caso segundo o Direito Positivo significa decidi-lo segundo a base de valorações e finalidades úteis para as quais foi constituida a própria ordem jurídica" 7

Esse ensinamento já evidencia o impasse. Na aplicação da norma jurídica ao.caso, o juiz está vinculado ao Direito Positivo, mas, ao mesmo tempo, não pode menosprezar os traços èxistenciais da situação conflitual.

Apesar do equacionamento dos fatores normativamente previstos, apresenta a situação $s u b$ judice traços característicos contingentes que o sistema nãorevela. Por outras palavras: o vínculo da relação intersubjetiva não corresponde in totum à previsão normativa. O Direito de normas é incapaz de fornecer ao juiz todos os elementos para a decisão.

A norma, nesta hipótese, é o "dado" A sentença, fruto do trabalho do juiz é o "construído" A construção prudencial é a operação que permite a determinação do Direito aplicável à espécie, em harmonia com os preceitos normativos e sem descuido dos fatores contingentes que emanam do caso.

O que o juiz pode acrescentar ao "dado" para realizar a sua construção? Quais os caminhos que deve percorrer para não-afetar a inteireza do dado? Qual é a posição do juiz? A interpretação judicial deve se conformar ao dogma legal, observando o magistrado, rigorosamente, o texto (legalismo) ou é

7. Coing, Helmut. Fundamentos de Filosofia del Derecho, trad. Juan Manuel Mauri, Barcelona, Ariel, 1976, p. 137. 
possível, a partir do esquema normativo, uma obra de construção (desenvolvimento e complementação judicial do Direito segundo a teleologia do sistema).

Uma visão panorâmica das principais escolas melhor evidenciará a contraposição doutrinária, esclarecendo, ainda, as razões que levam à filiação a uma ou a outra posição hermenêutica. A contraposição mostrará ainda a impropriedade do chamado "Direito alternativo" É o que Elias Diaz denomina a polêmica entre os métodos jurídicos, situando-se, de um lado, os formalistas e conceitualistas e, de outro, os finalistas e realistas. ${ }^{8}$

Trata-se, em suma, da possibilidade ou-não de adaptação do preceito genérico e sistemático a uma situação existencial com sua irrecusável singularidade e contingência. E na hipótese de possível adaptação a divergência dos métodos hermenêuticos convenientes à resolução do impasse.

Vejamos, então, como a contraposição entre o abstrato e o concreto se opera. Pode-se dizer que as concepções sobre a problemática se reduzem a três: a. as que preconizam o processo limitativo da subsunção legal; b. as que aconselham a interpretação livre e criadora; c. as que recomendam a interpretação criadora, coerente e dependente do sistema normativo. É o que sustenta Philip Heck na obra "O Problema da Criação do Direito"

A primeira corrente, denominada "Escola da Exegese" resolve a questão do binômio norma-caso de maneira simplista. Ante o pressuposto do caráter dogmático da lei, cujo texto deveria ser rigorosamente observado, sem o menor atrito, procuravam os exegetas circunscrever, delimitar e contornar a atuação judicial dentro de margens estritas.

Mas, como observa Luís Recasens Siches, esse modo de pensar é incoerente. Sem interpretação é impossível dinamizar qualquer ordenamento jurídico. O legislador só tem competência para editar normas genéricas, escapando de sua alçada, disciplinar o modo do exercício da função jurisdicional. Uma coisa é editar normas genéricas; outra é a de elaborar as normas individualizadas. Nenhum ordenamento jurídico pode ser aplicado sem a conveniente interpretação. ${ }^{9}$

Para a "Escola da Exegese", o intérprete deveria conhecer a vontade do legislador. A lei, vigente e positiva, seria violada se o intérprete ultrapassasse a

8. Diaz, Elias. Sociologia e Filosofia del Derecho, Madrid, Taurus, 1982, p. 106 e ss.

9. Recasens Siches, Luis. Tratado General de Filosofia del Derecho, $3^{\mathrm{a}}$ ed., México, Porrua, 1965, pp. 329-330. 
simples explicitação. Interpretar nada mais é do que explicar o direito legislado. Para explicá-lo deve o intérprete ater-se às palavras da lei, respeitando, sempre, a vontade do legislador. A interpretação literal e gramatical é a que mais atende a esse objetivo. Para a análise da norma eventualmente obscura, ambígua ou deficiente, podia o intérprete valer-se do método lógico e histórico, extraindo do texto todas as conseqüências nele incluídas, mas com integral respeito à vontade do legislador. A solução jurídica não podia fugir do método dedutivista e silogístico, sendo a vontade do legislador o fator decisivo da interpretação.

Semelhante interpretação redunda em conceitualismo artificial, com desconhecimento dos problemas sociais para os quais a lei foi editada. É o que ocorreu com a chamada "jurisprudência dos conceitos" pelo seu apego ao conceitualismo e desconsideração do jogo de interesses que se desenrola no processo judicial.

A Escola Histórica revela a mesma tendência exegética e dedutivista. Quando o texto do Corpus Juris Civilis foi incorporado ao Direito alemão, os pandetistas interpretaram-no segundo processos exegéticos. Mas, não se apegaram à razão e, sim, à história. Para os franceses, a lei era a fonte; para os alemães, o passado.

É certo que a Escola Histórica representava violenta reação ao racionalismo metafísico do Direito Natural Moderno. Esta última posição não considerava o processo histórico do desenvolvimento do Direito, em estrita harmonia com as condições culturais da época. Contra essa idéia de um Direito ideal, desvinculado da experiência é que reagiu a Escola Histórica.

O Direito é a expressão do espírito do povo, manifestando-se nos costumes. Estes traduzem a autêntica vida comunitária, gerando a norma consuetudinária. O Direito está enraizado no passado da nação, sendo a consciência comum do povo a sua fonte. Os costumes brotam espontaneamente e formam a regra da vida, de modo que o verdadeiro exame dos referidos costumes revela o preceito. O desenvolvimento do Direito é lento e gradual, como o da linguagem.

Mas, a recepção do Direito Romano, acima apontada, deu origem a uma hermenêutica jurídica lógica e dogmática, semelhante a dos intérpretes da Escola da Exegese. Contudo, revelaram os intérpretes compreensão histórica do fenômeno jurídico, sempre aberto à pesquisa dos fatores sociais da normatividade.

De suma importância é também a "jurisprudência dos conceitos." O atrito entre as estruturas de essência e a realidade existencial mais se agravou com a 
jurisprudência dos conceitos, cuja técnica não foi suficiente para dissolvê-lo. $O$ movimento caracterizou-se pelo princípio, segundo o qual os preceitos constantes da normas jurídicas revelam significações e conceitos lógicos. A lei deve ser vista no seu sentido lógico e sistemático.

Segundo o pensamento dessa corrente, o intérprete deve partir do texto e de seu significado no contexto do ordenamento. O jurista deve estudar a norma não-só na sua estrutura, mas no conjunto do sistema, extraindo, dessa pesquisa, critérios de orientação. O material é dado pelas normas jurídicas, alcançando o jurista, pela análise das conexões lógico-sistemáticas, os princípios informativos e as conclusões a que o sistema conduz. O jurista deve permanecer no material normativo, dele extraindo todas as implicações. A sua função é simplesmente reprodutora.

Estando os preceitos legais logicamente sistematizados já propiciam ao intérprete a solução do caso. A decisão judicial é mero corolário, deduzido, por inferência lógica, do sistema legal. A unidade do sistema jurídico está na concatenação lógica e a solução do caso no processo mecânico da dedução. A solução judicial decorre estritamente do sistema, pois os preceitos particulares promanam da definição conceitual.

Cabe, assim, ao juiz simplesmente a tarefa consistente em subsumir o caso no tipo. Nesta ordem de idéias, verifica-se que o dilema em estudo é resolvido pela adequação lógica no caso do tipo, como se o que existisse fosse o universal e não o singular.

Mas, o sistema jurídico não é, no fundo, simples sistema de proposições lógicas e, sim, de decisões valorativas. As normas são enunciadas logicamente. Têm sua estrutura. Contudo, o enunciado já reflete o conteúdo de valor protegido normativamente. Não se pode confundir a enunciação lógica com o conteúdo de valor que o preceito traduz.

O que existe não é a estrutura lógica e, sim, o real na sua objetividade. Portanto, não-basta a explicitação formal para a solução do dilema norma-caso. A função do juiz não pode se resumir numa operação de entendimento, isto é, em conhecer as normas e enquadrar, no texto, a situação litigiosa.

A desconsideração do finalismo não-possibilita, no nossio entender, o desate do dilema em estudo.

A concepção seguinte é a da "jurisprudência dos interesses" É necessário para desvendar a problemática da antinomia entre a norma e o caso, a 
consideração do fim, da finalidade de cada uma das instituições jurídicas. Mas, como posiciona Alfred Verdross, a jurisprudência dos interesses não chegou a proporcionar critério seguro para a aferição dos interesses, permanecendo encerrada no subjetivismo e no relativismo. ${ }^{10}$

Inegável, porém, o mérito de reconhecer $o$ processo de desenvolvimento do Direito, devendo o juiz orientar-se pelos fins sociais e exigências valorativas contidas no ordenamento jurídico.

A aplicação do Direito redunda num processo de inserção das regras nas situações de vida. Realmente, a norma jurídica tem um fim. Ela é elaborada para resolver conflito de interesses, conflitos reais decorrentes das situações de vida. Os interesses é que devem ser sopesados na elaboração e aplicação das normas jurídicas.

O critério efetivo de aplicação do Direito está, para a Escola Teleológica, na realidade social, no interesse juridicamente protegido. O novo dado, e fundamental, é o da pesquisa do fim, do interesse protegido pela lei, elaborada para reger as relações de convivência. Esse interesse se encontra na lei porque o legislador, ao elaborá-la, partiu da realidade social, elevando os interesses que desta dimanam, à categoria da juridicidade. Das necessidades sociais, surge a lei. Portanto, sua aplicação se guiará pelos mesmos princípios. A lei deve ser interpretada à luz dos interesses sociais para os quais a mesma foi ditada, à luz das situações de vida que ensejaram seu aparecimento.

O método eficaz de aplicação passa a ser o teleológico. É o caminho que conduz à realização dos interesses individuais e sociais, normativamente sopesados.

A vinculação do dilema norma-caso encontra solução mais satisfatória na medida em que a escola possibilita o Direito judicial de estimação, conforme critério já exposto. Contudo, Jhering não chegou a indicar nenhuma ordem objetiva de fins sociais. Na verdade, esta se correlaciona com a ordem dos valores, com uma tábua de valores. A idéia de Direito exige, em termos absolutos, uma referência à sua essência axiológica.

Mas, a Escola Teleológica combateu eficazmente o pensamento das escolas que the antecederam, abrindo margem a uma nova visão do problema

10. Verdross, Alfred. La Filosofia del Derecho del Mundo Occidental. Visión Panorâmica de sus Fundamentos e Principales Problemas, trad. Mário de la Cueva, Universidad Nacional Autônoma de Mexico, 1962, pp. 271-272. 
hermenêutico. Impossível pensar em interpretação sem atender à noção de fím das instituições jurídicas.

A Escola da Livre Investigação Científica merece especial destaque. De fato, François Geny foi quem indicou os meios através dos quais a adaptação do abstrato ao concreto se verifica, a saber, o processo das construções.

A atividade do jurista oscila entre dois pólos: o do dado e o do construído. O dado constitui objeto da Ciência; o construido, da Técnica. Os dados (reais, históricos, racionais e ideais), elementos necessários à construção do Direito legislado decorrem da própria "natureza das coisas" (conhecimento ontológico das dimensões da pessoa humana, bem como dos processos sociais). Cada fato social tem em si mesmo a norma que lhe é própria, decorrente de sua constituição ontológica. Esta norma própria da natureza exprime a orientação a ser seguida pelo Direito, legislado ou judicial. Tais dados, que se encontram na composição do Direito Positivo, devem ser acionados pela Técnica Jurídica. Esta é a técnica do construído.

A técnica consiste, de início, em procedimentos ou meios de adaptação dos dados abstratos a um fim, as realidades concretas. A norma, assim obtida, é editada pelo legislador, apresentando as características da generalidade e da abstração. Tais processos são necessários à Ciência do Direito. Constituem degraus do espírito rumo aos princípios da explicação universal. Mas o tipo implica na exclusão do contingente.

Também o juiz, na elaboração da sentença, deve se valer da técnica do construído, ou melhor, da intuição do justo e orientação à prática. O conhecimento judicial transcende o plano da conceituação.

Geny apresenta nova tese: a de que a lei não é a única fonte do Direito. Ao lado do Direito legal existe a produção jurídica decorrente das fontes formais e das fontes materiais. O Direito deve ser adaptado às transformações múltiplas da vida social.

Nestas condições, o intérprete deve, de início, recorrer à lei, devendo ser respeitada a vontade do legislador referente ao momento da sua promulgação. Mas, se a lei é omissa ou não atende mais às aspirações de Justiça, deve o intérprete se valer de outras fontes, a saber: o costume e a doutrina. Se estas ainda se revelarem insuficientes, cumpre recorrer às fontes materiais, representadas pela "natureza das coisas." Pode, então, o juiz criar a norma como se fosse o legislador. Se a lei se revela insuficiente ou ultrapassada, cumpre ao intérprete, proceder à "livre 
investigação científica" para encontrar a solução conveniente. É o que ensina Jean Louis Bergel."

A livre investigação científica não-obriga o juiz a efetuar a dedução silogística. Pelo contrário, a aplicação do Direito está sempre sujeita a uma solução que atenda às necessidades sociais e à eqüidade.

A Escola do Direito Livre envereda por caminho oposto. A lei nãoocupa o primeiro plano. A escola não-aceita a teoria da subsunção. A interpretação passa a girar em torno da figura do juiz. Cabe a este julgar segundo os ditames da própria consciência. $O$ desenvolvimento do Direito chega a reclamar sua interpretação praeter legem e contra legem. Cabe ao juiz legislar sempre que julgar inadequada a lei à espécie. Se a ordem legal é injusta por destoar das aspirações de Justiça, o juiz atua, corrigindo o Direito deficiente e aplicando a norma concreta e justa.

Uma coisa é a construção legislativa; outra, a construção judicial. Cabe a esta atender à realidade social. Por isso, Kirchmann e Kantorowicz admitem a existência de outro direito (o direito que o povo cria), ao lado do Direito estatal (o Direito codificado). Pretendem, assim, a liberação do "dado" normativo, quando determinadas circunstâncias o exigirem. É a construção livre da sentença.

As preocupações desta escola diferem das de Geny. Já não se trata de "livre investigação científica" em que o juiz capta o sentido do texto legal, construindo, a partir desse dado, a sentença, adaptada às necessidades sociais. Pelo contrário: o juiz pode livremente estabelecer a solução própria que o caso venha a exigir. Em Geny, existem parâmetros para a criação judicial. Na Escola do Direito Livre, o que importa é uma solução justa, baseada, porém, nos sentimentos de Justiça. É o Direito livre das estruturas lógicas. O juiz deve se preocupar mais com a realidade do que com a legalidade.

O dilema norma-caso não pode ser resolvido pela antecipação do caso à norma. A comunidade não pode viver à margem do Direito estatal, que se constitui de normas capazes de garantir a sobrevivência e desenvolvimento da sociedade. A comunidade necessita de certeza e de segurança a respeito de suas pretensões e obrigações.

Logo, o movimento em estudo não apresenta solução conveniente ao desate da questão. A função normativa é da essência ética do Direito, de modo que 
as soluções devem partir, necessariamente, da previsão legal e de sua base axiológica.

O normativismo de Kelsen, escola que abriu novos horizontes ao problema em questão, demonstra existir uma vinculação puramente lógica entre a previsão normativa e o caso, aquela representada pelas normas genéricas e este representado pelas normas individualizadas. A norma genérica é considerada fundante e a individualizada fundada, porque esta última é deduzida logicamente da primeira. Assim, a correlação entre a lei e a sentença decorre de procedimentos lógicos. O conteúdo da norma fundada já está predeterminado pela norma fundante, de modo que o dilema se resolve logicamente.

A correlação entre a norma superior ou fundante e a norma inferior ou fundada é inerente ao processo interpretativo, no qual as normas individualizadas dos negócios jurídicos, dos atos administrativos especiais e das sentenças judiciais se situam.

A posição de Kelsen, que se funda na concepção do Direito como ordem coativa da conduta humana, e se subsume num entendimento de ordem racionalista, não-possibilita o desate da questão formulada, por falta de bases axiológicas.

A sentença, para Kelsen, é um ato de vontade. O intérprete, não-só desvenda a norma genérica, como, também, opta por uma dentre as possibilidades normativas oferecidas pelo marco normativo. Sua escolha está delimitada pela estrutura normativa. Assim, a sentença não-resulta de uma simples operação de ordem intelectual, como pretendem os representantes das escolas tradicionais. Ela é mais do que isso. Escolhendo, no âmbito estrutural da norma, uma das possibilidades, o intérprete exerce um ato de vontade, fazendo surgir uma norma nova, de caráter individual.

Logo, a sentença é um ato de entendimento, um ato de vontade e um ato de criação normativa. Ao surgir a norma individualizada, não-intervém o processo valorativo, ou, se intervém, isto não interessa à hermenêutica jurídica. $O$ sentido axiológico ínsito na opção do intérprete está fora de cogitação, porque se refere a uma questão metajurídica. Basta que a escolha se insira no marco das possibilidades para que a solução seja considerada juridicamente válida.

Vejamos como o equacionamento se opera. O Direito contém normas que se encontram graduadas em escalões dentro de uma pirâmide hierárquica. Toda interpretação depende, em última análise, da colocação da norma na estrutura 
hierárquica. Uma norma depende de outra conforme a posição hierárquica. A norma fundante é que dá origem à fundada, e esta passa a ser fundante relativamente à inferior, e assim sucessivamente. $O$ processo hermenêutico está ligado a esse conhecimento prévio.

É a dinâmica jurídica. Kelsen diz que há, a respeito, cinco espécies de normas. De início, temos a norma fundamental. Esta é diferente de todas as demais, por ser uma norma básica, não-positiva, simples ponto de partida para a sustentação lógica das demais normas. É simples hipótese de ordem gnoseológica. A norma fundamental só diz que o primeiro legislador age com legitimidade e juridicidade. É, apenas, uma norma pensada, hipoteticamente. Não tem existência objetiva. Para que os mandamentos legais possam ser considerados obrigatórios é indispensável supor a existência de uma norma fundamental, que admita a legitimidade do poder e o dever de obediência da comunidade. A ordem coativa da conduta humana, como sistema de normas obrigatórias, promana do referido axioma da teoria formal do Direito. Teoria que, no nosso entender, não-desvenda o problema fundamental do Direito e não-esclarece a natureza da interpretação jurídica. Como decorre o Direito de um enunciado sem conteúdo?

À norma fundamental seguem-se as normas constitucionais. Ocupam estas o segundo plano. Dizem respeito à organização do Estado, bem como as competências dos poderes legitimamente constituídos e suas relações com os membros da comunidade. A estes últimos são atribuídos direitos e garantias individuais.

Em terceiro lugar, surgem as normas ordinárias, isto é, todas as leis que prevêem as relações sociais básicas. Dizem respeito ao equacionamento dos poderes e deveres dos membros da comunidade, referentes às diversas situações de vida. Ao lado destas normas ordinárias devem ser colocadas as normas costumeiras. O costume, embora fonte subsidiária, opera na falta de lei, pertencendo, ambos, ao ordenamento jurídico.

Em quarto lugar, encontramos as normas regulamentares, elaboradas pelos órgãos administrativos. Estas visam disciplinar e complementar preceitos das normas ordinárias quando os mesmos não são auto-aplicáveis. São provenientes de delegação expressa das próprias normas ordinárias para especificar os preceitos ou simplesmente para suprir as omissões legais. Aqui se trata do ato administrativo geral, que não se confunde com o especial. Convém relembrar a lição de Ranelletti, in verbis: "ato administrativo, em sentido formal, pode ser geral ou especial. É 
geral se a declaração que constitui o ato administrativo considera abstratamente uma pluralidade de pessoas, ou casos indeterminados ou indetermináveis. É especial se a declaração que possui o ato administrativo considera uma ou mais pessoas ou casos determinados ou determináveis" 12

Os primeiros (atos administrativos genéricos) têm alcance geral e se manifestam nos regulamentos; os segundos (atos administrativos especiais) têm alcance restrito e se manifestam em normas individualizadas, contendo pretensões concretas e destinatários certos. As normas regulamentares dizem respeito aos atos administrativos genéricos.

Em quinto lugar, estão as normas individualizadas. São normas que concretizam situações prospectivamente previstas nas normas anteriores. Tem caráter secundário e descendente relativamente às normas genéricas. Permitem transpor, para a situação convivencial concreta, as previsões das normas genéricas. Decorrem de um sistema de delegações (complementação autorizada), sendo sua elaboração conseqüência da atribuição concedida, pelas normas superiores, aos agentes públicos (juízes e órgãos da administração) e membros da comunidade para a disciplina de determinadas relações jurídicas específicas.

As normas genéricas são paradigmas de que se valem as normas individualizadas para estabelecer o jus e o debitum relativos a uma situação concreta. São, portanto, complementares. Segundo Eduardo Garcia Maynez, dividem-se em privadas e públicas. Diz o jurista que "as primeiras derivam da vontade dos particulares, enquanto estes aplicam normas genéricas; as segundas, da atividade das autoridades. Tem caráter privado os contratos e os testamentos; público, as decisões judiciais e as resoluções administrativas. Os tratados contratos internacionais devem caracterizar-se também como individualizadas de indole pública" $^{13}$

Assim sendo, as normas individualizadas são imperativos autorizantes específicos. Através delas se opera a passagem do plano abstrato ao concreto com as implicações que a simples dedução deste último com relação ao primeiro pode operar.

12. Ranelletti, Oreste. Teoria Degli Atti Amministrattivi Speciali, $7^{\mathrm{a}}$ ed., Milão, Giuffrè, 1945, pp.

13. Garcia Maynez, Eduardo. Introducción al Estudio del Derecho, 16a ed., México, Porrua, 1969, pp. 83-84. 
Surge, nesta altura, a questão: daria esta simples dedução a medida do justo, a Justiça do caso concreto, assim englobado e costurado na trama do ordenamento jurídico? Estaria aí a resolução do dilema norma-caso, objeto da presente pesquisa?

O sentido lógico não pode estar desconectado do sentido axiológico. Como explica Helmut Coing, "as normas juridicas não são axiomas lógicos para deduções juridicas, já que reproduzem experiências morais e idéias jurídicas" Em conseqüência, "a aplicação do direito deve partir sempre de pontos de vista valorativos subjacentes à ordem jurídica e julgar a situação segundo seus caracteres essenciais e não segundo sua estrutura formal" 14

Os esquemas formais da lógica se constituem em "instrumentos da ciência" ou "meios para adquirir e possuir a ciência" Portanto não podem se confundir com a própria ciência dirigida. Jacques Maritain diz expressamente: " $a$ Lógica Formal estuda, pura e simplesmente, o mecanismo do raciocínio, abstração feita do conteúdo mesmo das proposições que emprega e do uso que o espírito dele faz" ${ }^{15}$ Da mesma forma, ensina Paul J. Green: "a Dialética é a ciência do pensamento correto. Correção significa ordem, consistência, legitimidade do procedimento, justificação da inferência. Ela não significa verdade. Dialética é, assim, a ciência do pensamento correto, não do pensamento verdadeiro ou certo". ${ }^{16}$

A consideração de meras estruturas lógicas não é suficiente para a compreensão de conteúdos espirituais, segundo adverte Coing. ${ }^{17}$ E a crítica se endereça a Kelsen porque este jurista considera a ciência do Direito como ciência do espírito.

Mas, retornando à questão, cabe salientar que na passagem do quarto para o quinto plano da pirâmide coloca-se o substractum do problema. As normas que antecedem ao último plano são todas genéricas (exceto a norma fundamental, que não é coativa), enquanto que, na elaboração das normas individualizadas, entra em jogo uma situação de vida com as suas características contingentes. Os elementos típicos e as circunstâncias do caso não são postos em evidência, já que não se

14. Coing, Helmut. Obra cit., pp. 276-279.

15. Maritain, Jacques. Elementos de Filosofia, A Ordem dos Conceitos, Lógica Menor, trad. Ilza das Neves e Adriano Kury, São Paulo, Agir, 1980, pp. 26-27.

16. Gleen, Paul J. Dialectics. Class Manual in Formal Logic, St. Louis, Herder, 1949, p. 13 (Introduction).

17. Coing, Helmut. Obra cit., p. 293. 
inserem no conteúdo predeterminado das normas genéricas. Não há, assim, um processo de decisão justa de um litígio concreto.

A interpretação, no sistema de Kelsen, não passa de simples explicitação da ordem formal. $O$ entendimento da norma genérica dá origem a um marco de possibilidades legais. O juiz apenas opta por uma delas, exercendo, assim, sua vontade e criando a norma individualizada. Esta é, acima de tudo, um ato de vontade e de criação: de vontade, porque o intérprete não-só descobre o que a norma diz (fase intelectual), como e principalmente porque opta por uma dentre as possibilidades oferecidas pelo marco normativo (fase de ordem voluntária); e de criação, porque escolhendo e aplicando, o intérprete faz surgir uma norma nova, individualizada, para o caso concreto (fase criadora).

A interpretação acompanha o processo de criação do Direito, por ocasião da passagem de uma norma superior e uma inferior. Ao interpretar, o juiz não se coloca numa posição puramente intelectualista (pesquisa da solução possível); exerce um ato de vontade porque, ao passar de uma norma a outra, opta por uma solução; e exerce um ato de criação, porque, optando, cria a norma para o caso sub judice.

Como se processam o ato de vontade e o ato de criação? De início, cabe dizer que a norma superior, de antemão, delimita o conteúdo da norma inferior, de maneira incompleta. Há sempre algo que fica à livre apreciação do intérprete. Há uma indeterminação na norma, indeterminação que deve ser preenchida por ocasião da tarefa interpretativa. A indeterminação pode ser intencional, como nos casos de crimes de penas paralelas e pode ser não-intencional, como no caso do uso de termos equívocos, de enunciados legais que comportam entendimentos não-unívocos, isto é, equívocos ou análogos.

A indeterminação do legislador não é outra coisa senão o aspecto abstrato, genérico e sistemático de que se reveste a norma jurídica. Por isso, cabe a individualização. A passagem do genérico ao específico não pode ser simples escolha de uma possibilidade, mas a conversão dessa possibilidade genérica em específica. Isto só é possível levando-se em conta as peculiaridades do caso. Logo, a opção é um escolha motivada, que atende à natureza da coisa.

Em suma: o marco das possibilidades já revela valores, que devem ser atualizados pelo processo do discernimento prudencial. A prudência é o elo entre o Direito legislado, de caráter abstrato, e o Direito judicial, de caráter concreto. Só a solução prudencial permite a resolução do impasse, porque tem como propósito estar 
vinculada e dependente do sistema normativo e, ao mesmo tempo, atender ao caso, revestido de seu modo de ser contingente.

Só a prudência permite a aplicação eqüitativa do Direito.

Por todo o exposto, parece-nos que a teoria normativista não-resolve a antinomia norma-caso. Sem valoração não pode surgir a norma individualizada. É a prudência que intervém entre o "direito de normas" e a "jurisprudência da eqüidade" (estas expressões são de Henkel).

Merece especial destaque a corrente do realismo sociológico americano. O movimento desaprova a solução puramente formalista e acentua a necessidade de ponderar as diretrizes valorativas imanentes às realidades sociais. $\mathrm{O}$ Direito não é pura lógica e, sim, instrumento para a obtenção de resultados práticos, a saber, o bem-estar social. Indispensável, portanto, o conhecimento sociológico dos interesses privados, sociais e públicos que demandam proteção jurídica. É o que salienta Roscoe Pound em sua obra Social Control Through Law. Tarefa do Direito consiste em proteger eficazmente os interesses normativamente reconhecidos.

Apesar das divergências entre a família dos sistemas latino-europeus e a do sistema anglo-americano, também, neste último, se verifica a antinomia normacaso, que temos estudado. Os juristas americanos chegam a proclamar que o essencial não é a solução puramente lógica do dilema, mas, sim, sua solução justa. Eles exigem, para esse desiderato, estudo sociológico da realidade social. Não se pode esquecer que o Direito nasce dos fatos, da experiência.

Nos sistemas latino-europeus, as normas individualizadas das sentenças provêm dos princípios contidos nas normas genéricas dos códigos. No sistema anglo-americano, as decisões procedem de outras decisões anteriores (ratio decidendi), relativas a casos individuais, de onde são extraídos os princípios para cada julgamento.

Cabe-nos, assim, examinar os dilemas resultantes da ratio decidendi do precedente, que aborda determinado caso e sua configuração, e a do caso sub judice, cujos aspectos, como não poderia deixar de ser, não-coincidem, na totalidade, com o primeiro. Além dessa hipótese, pode ocorrer omissão do precedente (nossa lacuna), situação que se resolve, segundo Bodenheimer, "por uma analogia que assenta num interesse social comum aos casos já decididos e ao que está em julgamento". ${ }^{18}$

18. Bodenheimer, Edgar. Ciência do Direito. Filosofia e Metodologia Jurídica, Rio, Forense, 1966, p. 306. 
A ratio decidendi, diz Bodenheimer, é o "princípio geral que governa a decisão anterior, quando a formulação desse princípio tenha sido necessária para a decisão do ponto fundamental do litígio" 19

A lição de Ilmar Tammello, publicada em estudo sobre La Règle du Droit é, a respeito, a seguinte: "para a descoberta da 'ratio decidendi' de um caso, o juiz não deverá considerar todas as expressões normativas que se encontram na relação do caso, mas somente aquelas que são indispensáveis à elaboração da decisão do caso examinado. Todo o resto constitui o obier dictum, suscetivel de trazer contribuição para a Ciência do Direito, mas impertinente para a decisão do caso" $^{20}$

A resolução do dilema norma-caso estaria, segundo a escola sociológico-americana, na compreensão da realidade social e na visão dos interesses que esta realidade traduz. Edgar Bodenheimer, já citado, salienta "a necessidade de avaliação judiciosa e ampla de tudo quanto possa contribuir para um julgamento refletido" e acrescenta que "julgamento refletido é o que se inspira na 'natureza da coisa' e traduz a eqüidade individual como solução justa da contenda" 21

Oliver Wendel Holmes, outro representante da escola, foi o primeiro a salientar que "a vida do direito não foi a lógica e, sim, a experiência" Diz o jurista: "as necessidades sentidas em cada época, as teorias morais e políticas predominantes, intuições de ordem pública declaradas ou inconscientes, até precedentes que os juizes compartilham com seus semelhantes, tiveram participação bem maior do que o silogismo, na determinação das normas que deveriam dirigir os homens". 22

De forma idêntica, Benjamim Cardozo põe em discussão os métodos interpretativos. Dos quatro métodos existentes - o dedutivo, o histórico, o das idéias inspiradoras e o do ideal de Justiça - este último é que tem proeminência. Este é o método decisivo. A Justiça não decorre da análise do precedente sendo mais importante chegar à Justiça do que a uma solução lógica.

19. Bodenheimer, Edgar. Obra cit., p. 306.

20. Tammello, Ilmar. La "ratio decidenti"et la Règle du Droit, in La Régle du Droit, estudos publicados por Chaim Perelman, pp. 123 e ss.

21. Bodenheimer, Edgar. Obra cit., p. 409.

22. Holmes, Oliver Wendell. O Direito Comum, pp. 27 e ss. 
Por fim, Roscoe Pound mostra que a obra de um jurista pode ser comparada à de "engenharia social". O Direito equaciona e compõe interesses sociais conflitantes e em contínua mutação. Tanto o legislador quanto o juiz devem se inspirar em pautas axiológicas para a composição e resolução de conflitos de interesses. A função do legislador e a do juiz estão mutuamente implicadas: a do legislador consiste em elaborar normas jurídicas; a do juiz, em complementar, desenvolver, conformar os preceitos destas à realidade da situação conflitual concreta. ${ }^{23}$ Logo, o juiz prolonga a obra do legislador, como causa segunda.

Para a jurisprudência sociológica, o Direito é instrumento para a obtenção de fins sociais. Não pode a sentença ser simples dedução silogística do precedente. Deve traduzir a eqüidade.

Parece-nos útil, para finalizar, algumas considerações sobre o realismo sociológico escandinavo. Os juristas escandinavos também se preocupam com a realidade em que se funda o Direito. Mas, repudiam a idéia de valor como fundamento do Direito. Não há vinculação entre o Direito e as exigências éticas.

A Escola de Upsalla admite como ilegítima toda e qualquer especulação a respeito da idéia de justo ou injusto. Estas afirmações não podem ser verdadeiras nem falsas, como, aliás, proclama o neopositivismo. A lei não contém nenhuma vinculação axiológica. É puro fato. É o fato da força organizada.

Um de seus representantes, Karl Olivecrona, diz o seguinte: "sem dúvida, a vida social deve se apoiar no direito. Mas, não no direito em sentido metafísico, isto é, no direito imaginário colocado sobre os fatos com a sua suposta força obrigatória. Não, nossa vida social se baseia no direito efetivo, no direito como fato, tomado no sentido de força organizada que se utiliza de normas chamadas leis em sentido estrito... Os homens precisam ser domesticados para poder conviver pacificamente" 24

A norma jurídica deixa de ser um esquema de valor para se converter em instrumento de canalização da força.

A sentença que decorre da norma jurídica é, da mesma forma, um instrumento de canalização da força. A sentença é a medida da força canalizada para o concreto. Diz Olivecrona: "o juiz discerne o uso da força nas matérias reguladas

23. Pound, Roscoe. Introducción a la Filosofia del Derecho, trad. Fernando Barrancos y Vedia, Buenos Aires, Tip. Ed. Argentina, 1972, cap. III.

24. Olivecrona, Karl. El Derecho como Hecho, trad. José Júlio S. Pinter, Buenos Aires, Depalma, 1949, p. 13. 
pela legislação civil e pela legislação penal, mas o seu poder está restrito aos estritos limites das normas legais... É, assim, que o poder de dirigir a força, posto nas mãos dos juizes, está estritamente regulado e canalizado" 25

Contra essa posição se coloca o jurista norueguês Fred Castberg, proclamando que, em toda regra de Direito há uma exigência de Justiça. Em sua obra La Philosophie du Droit ensina: "do ponto de vista da Filosofia do Direito, tudo o que pode ser dito sobre a apreciação correta do Direito Positivo implica, em si, uma valoração de normas. Trata-se de valorações que, direta ou indiretamente, colocam a questão do que é bom ou mau nas ações humanas. Para a ordem jurídica é importante ter contato com as exigências da Moral" ${ }^{26}$

O realismo escandinavo, negando o fundamento ético da norma jurídica, se dissocia do humanismo jurídico, não-possibilitando o desate correto da antinomia em estudo, que requer solução dependente da intuição do justo, presente em toda a situação de vida. Para eles, o problema ético ultrapassa o campo das investigações científicas. É de ordem subjetiva.

É a tragédia da cultura a que se refere Jacques Maritain, na sua obra Humanismo Integral: "consiste o terceiro momento (o da tragédia da cultura) em um recalcamento progressivo do homem pela matéria. Para reinar sobre a natureza sem consideração às leis profundas de sua natureza, é obrigado o homem, em sua inteligência e em sua vida, a se subordinar, cada vez mais, a necessidades não humanas, mas técnicas e às energias de ordem material que desenvolvem e invadem o mundo humano'. 27

De acordo com a orientação que vimos imprimindo a esta pesquisa e tendo em conta aos óbices já opostos às teorias anteriores, pensamos que a resposta à questão formulada está na consideração de que os preceitos legais são, por natureza, de fundo ético, já contendo, em si, uma escala e medida para ulteriores valorações. Os preceitos se fundam, em última análise, no estatuto ontológico da pessoa humana e traduzem valorações para a convivência humana. Estas valorações passam a constituir a teleologia imanente ao sistema, base para a elaboração das normas individualizadas.

25. Olivecrona, Karl. Obra cit., pp. 105 e ss.

26. Castberg, Fred. La Philosophie du Droit, Paris, A. Pedone, 1970, pp. 3 e 43.

27. Maritain, Jacques, Humanismo Intregral, p. 27. 
Exerce o juiz, na aplicação da lei, uma função cognoscitiva. Tendo conhecimento da estrutura material das normas exerce, ainda, uma função criadora, coerente e dependente do sistema, de acordo com o sistema de referência consagrado pelo legislador. Ao elaborar a norma individualizada, o magistrado vivencia e traduz, para o caso concreto, os valores subjacentes ao sistema. Esta tradução depende de juízo prudencial, porque devem ser sopesadas e atendidas as exigências juridicamente relevantes do caso sub judice.

O método ideal está na jurisprudência dos valores, a única que corresponde à natureza ética do ser jurídico. O valor é a energia vital da norma jurídica e a chave para a resolução da antinomia norma-caso.

A prudência é, no nosso entender, o caminho certo para a atualização e concretização dos valores, porque ela permite estabelecer uma ponte entre o Direito legislado, abstrato e genérico, e o Direito judicial, específico e concreto. Ele possibilita a aplicação eqüitativa do Direito.

A sentença é, assim, um ato de construção prudencial: de construção, porque o juiz, de uma norma genérica, que é o dado, cria uma norma individualizada, concretizando, assim, a "mens legis"; e prudencial, porque esta construção, vinculada à "teleologia imanente ao sistema" não deixa de levar em conta os traços essenciais da situação conflitual, atendendo, assim, à "natureza da coisa"

Quais são os procedimentos hermenêuticos que atendem a semelhante desiderato? É o que pretendemos responder nos capítulos subseqüentes.

4. Resolução do dilema norma-caso. Análise dos procedimentos hermenêuticos.

Pode-se dizer que a aplicação prudencial do Direito envolve atividades complexas. De início, cabe ao juiz a observação, a análise do fato realmente ocorrido, o que depende de percepções e avaliações de circunstâncias singulares. Em segundo lugar, apresenta-se a fase do enquadramento do fato na hipótese normativa, bem como a qualificação jurídica do caso como fato prefigurado na norma. Finalmente, a eleição do preceito aplicável, cujas conseqüências jurídicas devem traduzir o justo concreto, isto é, a eqüidade.

Para o cumprimento das tarefas acima enumeradas, o juiz conta com normas que contêm tipificação correta (as que descrevem os fatos genericamente); conta com normas que contêm, algumas vezes, tipificações que destoam dos ideais 
de Justiça; conta com normas que apresentam preceitos conflitantes; e conta com normas que apresentam omissões relativamente a determinados casos.

Assim sendo, ocorrem quatro situações: situação de previsão genérica, quando as normas são adequadas para o caso concreto; situação de imperfeição, quando as normas destoam dos ideais de Justiça; situação de incoerência, quando as normas contêm preceitos contraditórios; e situação de insuficiência, quando faltam preceitos que deveriam existir para a solução do caso.

Em todas essas hipóteses, a atuação é, sempre, prudencial, porque o juiz deve, em todas elas, traduzir o justo concreto, seja pela adaptação do Direito, seja pela correção, seja pela integração normativa.

A primeira situação demanda interpretação da norma jurídica; as demais exigem o desenvolvimento do Direito.

Não é suficiente, nestas hipóteses, enquadrar o fato na lei. É preciso ver se a subsunção corresponde ao Direito justo. John C. Gray, da escola pragmático-sociológica, assinala: "the function of a judge is not mainly to declare law, but to maintain the peace by deciding controversies"

Logo, o juiz, agindo com prudência, completa a obra do legislador contribuindo para o aperfeiçoamento do Direito.

S. Belaid, realçando o poder normativo e criador do juiz, salienta que o ordenamento jurídico tem sua existência condicionada por três fatores: a continuidade, a evolução e o progresso. Cabe ao juiz salvaguardar o cumprimento dos preceitos legais, a evolução e adaptação destes e o aperfeiçoamento da ordem sistemática. Sem esta participação judicial, o Direito não se realiza, não-evolui e não-progride. ${ }^{28}$

Isto posto, releva estudar, agora, como se verifica a construção prudencial na adaptação, no desenvolvimento e no aperfeiçoamento do Direito.

Seguindo a orientação de Marcelino Rodriguez Molinero, constante de sua obra Introducción a la Ciencia del Derecho deve-se considerar, de início, a interpretação dos esquemas normativos, que exigem considerações de ordem valorativa para a obtenção da solução justa. O desenvolvimento homogêneo, segundo tema a ser analisado, desdobra-se, de acordo com o mencionado jurista, em duas questões: a do desenvolvimento intra-legem, que abrange problemas relativos à

28. Belaid S.. Essai sur le Pouvoir Créateur et Normatif du Juge, Paris, Librairie Gẻnèrale du Juge, 1974. 
coerência lógica (antinomias normativas) e insuficiência de normas (lacunas); e a do desenvolvimento praeter-legem ou supra-legem, que diz respeito à solução de casos em que as hipóteses normativas colidem com as aspirações de Justiça.

A adaptação da norma ao caso será examinada no presente capítulo. $\mathrm{O}$ desenvolvimento intra-legem e supra-legem no subseqüente.

A adaptação dos esquemas normativos ao caso em julgamento exige os seguintes procedimentos: a. conhecimento dos esquemas normativos; b. avaliação dos fatos segundo juízos de valor contidos no sistema; c. qualificação jurídica; $d$. mensuração das conseqüências; e. elaboração da norma individualizada.

Vejamos as dificuldades correspondentes ao conhecimento dos esquemas normativos. A primeira é que se refere à linguagem. É a linguagem que dá o contorno do discurso normativo. Heinrich Henkel salienta ser a linguagem "veículo de conteúdos juridicos" Os signos lingüísticos sustentam o sentido do Direito. ${ }^{29} \mathrm{~A}$ outra diz respeito ao conceitualismo que preside a configuração normativa, jáassinalada ao longo deste trabalho.

Pois bem, as etapas a serem percorridas para a superação desses obstáculos estão consubstanciadas em três métodos: o semântico, o sistemático e o teleológico. Conhecido o esquema normativo, a aplicação deverá levar em conta a "teleologia imanente ao sistema" e as circunstâncias juridicamente relevantes do caso concreto. Só assim será superada a generalidade e adaptado o preceito à situação convivencial.

A resultante desse processo é a eqüidade. Não há jurisprudência sem eqüidade.

Vejamos a interpretação semântica. Diz Pierre Pescatore que "esse método tem por objeto a apreciação dos signos do texto legal. Estamos habituados a falar a este propósito de interpretação textual, literal, ou ainda gramatical; entretanto, a expressão método semântico significa mais do que essas interpretações: ele coloca em relevo o fato de que as palavras e as orações de um texto legal são portadoras de um sentido, de um significado" ${ }^{30}$

As palavras da lei podem sofrer alterações semânticas, podendo assumir diferentes significados. É o que pode ocorrer com toda a expressão de um

29. Henkel, Heinrich. Obra citada, p. 85.

30. Pescatore, Pierre. Introduction a la Science du Droit, Luxembourg, Presses Universitaires, pp. 566 e ss. 
texto legal. Para que estes possam ser suscetíveis de aplicação aos casos concretos torna-se necessário atender ao impacto das valorações novas que podem ocasionar novo entendimento do texto legal.

Além disso, cumpre assinalar a intercorrência de outras normas que interferem na linha de interpretação dos esquemas normativos. Mas, não é só: as mesmas palavras podem ter, nos diferentes ramos do Direito, diferentes significados, já que os mesmos definem, por sua conta, os conceitos de que se utilizam. Interfere, em tudo isso, o problema do conceitualismo jurídico, entendido este como o conjunto dos processos utilizados par a elaboração do sistema normativo.

Pelo método semântico, o intérprete chega à análise do sentido exato dos vocábulos e das proposições. Atinge, assim, a compreensão, sob o ponto de vista sintático, da norma legal. Passa entender o que a norma expressa.

Os substantivos, adjetivos, verbos e conjunções são signos que revelam o entendimento da norma. Além disso, há linguagem técnica: esta consiste na análise dos conceitos jurídicos descritivos e normativos, determinados ou indeterminados, os quais revelam a significação jurídica hábil ao entendimento do texto. Tem razão Kelsen quando assinala que as normas comportam um "marco de possibilidades", porque o legislador se utiliza, propositadamente ou-não, de conceitos indeterminados. Deve-se atender à extensão e compreensão destes para a correta apreciação do sentido e alcance dos preceitos normativos.

Referidos conceitos descritivos e normativos exigem maiores cuidados. Jürgen Baumann esclarece: "as características do tipo que a lei emprega tem natureza extraordinariamente diferente. Existem, de um lado, características simplesmente descritivas, as chamadas características descritivas do tipo e, por outro lado, características que exigem do intérprete uma valoração: são as caracteristicas normativas do tipo. $O$ deslinde entre as características descritivas $e$ normativas é fluido. Também a característica normativa tem uma certa descrição $e$ também a característica descritiva não é simplesmente descritiva. Neste sentido pode-se dizer que todas as características são mais ou menos normativas" 11

No campo do Direito Penal, a caracterização da culpa, em qualquer de suas modalidades (imprudência, negligência ou imperícia), depende da consideração da previsibilidade. Esta resulta de um julgamento sobre as circunstâncias concretas

31. Baumann, Jürgen. Derecho Penal. Conceptos Fundamentales y Sistema, trad. Conrado A. Finzi, Buenos Aires, Depalma, 1973, pp. 78 e ss. 
do fato e a situação do agente. $\mathrm{O}$ acusado só responde pela previsão do que poderia ter e deixou de ter. Outro exemplo: a medida de repulsa, na legítima defesa, depende da violência da agressão, mas é certo que entre uma e outra deve existir proporcionalidade. Cabe ao intérprete examinar esta proporcionalidade, não-só em relação aos meios como também em relação ao grau. É a lição de Giuseppe Maggiore. $^{32}$

Além disso, os standards exigem idênticas valorações. Distingue-se na tipologia das normas jurídicas, normas de Direito estrito e normas diretivas. Nem sempre a lei contém preceito preciso e rígido. A norma, muitas vezes, deixa às partes e ao juiz um poder razoável de apreciação das circunstâncias. Nos standards, o legislado apenas apresenta uma diretriz, deixando larga margem de apreciação ao discernimento do juiz. São standards a regra relativa "ao prudente arbítrio do juiz" ou a que se refere ao poder discricionário do administrador que, atendendo à oportunidade e conveniência de certas medidas, pratica o ato administrativo. Como relembra Hart, a expressão "due care" do Direito anglo-americano é também diretriz, cuja avaliação deve ser feita de acordo com a experiência comum em cada caso concreto. $^{33}$

O segundo critério é o sistemático. Não se pode entender o significado de uma norma sem a pesquisa de sua situação, no conjunto normativo.

Não é suficiente deslindar os elementos integrantes da estrutura normativa: o fato jurídico, a prestação, a transgressão e a sanção, bem como os respectivos destinatários. A norma se insere no sistema. É preciso ver seu significado no conjunto do ordenamento jurídico.

Toda norma jurídica é parte de um todo. Tem razão Hans Kelsen ao salientar que o Direito é um sistema de natureza dinâmica. Há um princípio dinâmico capaz de articular, em forma de sistema, todas as normas jurídicas. A conformação interna do sistema revela a existência de um todo unitário, coerente e pleno.

Assim sendo, a análise da disposição normativa no contexto tem por objeto elucidar o sentido que a mesma adquire no confronto com as demais normas.

A interpretação sistemática provém do fato de que o ordenamento jurídico constitui uma unidade objetiva, como assinala Hans Nawiasky.

32. Maggiore, Giuseppe. Principi de Diritto Penale, Parte Generale, Bologna, Zanichelli, 1937, v. 1, p. 277.

33. Hart, H. L. A., El Concepto de Derecho, trad. Genaro, R. Carrio, Buenos Aires, Abeledo Perrot, 1968, p. 165. 
Realmente, as palavras podem mudar de significado segundo o contexto em que são empregadas. $O$ entendimento proveniente do método semântico é provisório, necessita de convalidação pelo processo sistemático.

As fases deste procedimento são três: a análise do contexto formal, a do contexto material e a do contexto hierárquico. É o que preconiza Pierre Pescatore. Considerando-se o primeiro aspecto (formal), é preciso localizar o preceito dentro do capítulo, o capítulo dentro do título, o título dentro da secção, e assim por diante. Cumpre atender à divisão sistemática da matéria nos Códigos. A seqüência hierárquica da divisão dos tipos na Parte Especial do Código Penal já revela conexões axiológicas relativas aos bens jurídicos penalmente tutelados. $\mathrm{Na}$ codificação há sempre um corpo orgânico de normas, revelando elementos lógicos indispensáveis à pesquisa hermenêutica.

Levando em conta o segundo aspecto (material), deve-se considerar a visão normativa da instituição a que a norma pertence. Esta colocação já revela princípios gerais que dimensionam as normas particulares. Finalmente, é mister não esquecer o contexto hierárquico. Sabemos que, segundo o princípio da hierarquia, formulado por Hans Kelsen, as normas estão distribuídas em degraus ou patamares, havendo, entre elas, relações de compatibilidade no plano vertical. Umas se subordinam às outras, tendo por base a norma fundamental. O processo da dinâmica jurídica demonstra a existência desses níveis distintos de preceitos jurídicos. $\mathrm{O}$ conteúdo de uma norma já vem predeterminado pelo conteúdo da norma que the é superior. Logo, não se pode interpretar um regulamento administrativo sem levar em consideração a norma legal que constitui seu suporte. Não se pode interpretar esta última sem estabelecer conexão com a Constituição. Em suma: a norma fundada só pode ser compreendida à luz da norma fundante.

A interpretação sistemática, permitindo estabelecer ligações entre a norma e o ordenamento, bem como conexões entre normas que se situam no mesmo plano da pirâmide, dá ensejo a uma nova compreensão do preceito, possibilitando sua aplicação em harmonia com o sistema.

Convém relembrar que a interpretação sistemática, implica, sempre, um ato de valoração. Ao perceber as conexões lógico-sistemática, percebe o intérprete, também, as conexões axiológicas que a estrutura revela. Toda interpretação conduz a uma objetividade axiológica. É necessário que o intérprete procure uma solução que, além de ser coerente com o sistema, seja, também, justa. 
A interpretação sistemática já revela os primeiros passos para a consideração da finalidade.

A terceira etapa do processo é a interpretação teleológica. Todo o processo hermenêutico se funda sobre a "teleologia imanente ao sistema" É o processo hermenêutico que procura a ratio legis, sua finalidade, vivencia e atualiza as decisões de valor consagradas na lei, como ensina Pescatore. Com efeito, a pesquisa metodológica tem como ponto de partida a análise do texto, continua com a indagação sobre o sentido do texto no contexto do sistema e culmina com a descoberta dos valores que sustentam a ordenação sistemática. É o que explica o mesmo Pierre Pescatore. ${ }^{34}$ No mesmo sentido de seqüência metodológica destinada ao conhecimento dos valores é a lição de Hans Heinrich Jescheck. ${ }^{35}$

Toda interpretação, como dissemos, é fundada sobre a teleologia imanente ao sistema. As normas jurídicas consagram valores sociais. Realmente, a norma jurídica tem por objetivo disciplinar a conduta social para que os membros da comunidade possam, num clima de respeito mútuo, atingir seus próprios objetivos, ou seja, os fins existenciais a que se refere Johannes Messner. ${ }^{36}$ A fonte axiológica do Direito é constituída pelos valores da pessoa humana. O jus e o debitum fundamentam-se, em última análise, no estatuto ontológico da pessoa humana. Logo, a norma jurídica não pode ser apreciada apenas no seu aspecto semântico e na sua formulação lógica. É imprescindível destacar o aspecto substancial, descobrir os esquemas de valor que a estrutura lógica exprime. Além da revelação da norma decorrente de seu aspecto lógico, é certo que a norma participa dos objetivos das instituições e do sistema a qual ela se insere.

É igualmente certo que o sistema contém, necessariamente, uma hierarquia de valores que as normas traduzem. A hierarquiam lógica já implica na hierarquia axiológica. O sentido teleológico é imanente ao sistema, estando ínsito no próprio processo de conversão de uma norma a outra. Por isso, é a teleologia imanente ao sistema que proporciona subsídios necessários à sua correta interpretação. A essência do ato de interpretação do Direito, como esclarece Helmut

34. Pescatore, Pierre. Obra cit., pp. 566 e ss.

35. Jescheck, Hans Heinrich. Tratado de Derecho Penal, trad. S. Mir Puig e F. Munhoz Conde, Barcelona, Bosch, 1981, p. 210.

36. Messner, Johannes. Ética Social, Politica e Económica a la luz del Derecho Natural, trad. J. L. Barrios Sevilla, J. M. Rodriguez Paniagua y Juan E. Diez, Madrid, Rialp, pp. 39 e ss. 
Coing, deve revelar, antes de mais nada, os valores em que se assenta a norma jurídica. ${ }^{37}$

Do mesmo entender participa Reinhardt Maurach ao salientar "que o instrumento decisivo na interpretação do direito deve radicar na finalidade do preceito jurídico penal no momento de sua aplicação" ${ }^{38} \mathrm{O}$ jurista se refere ao Direito Penal mas é certo que o conceito emitido diz respeito à interpretação de toda e qualquer norma jurídica.

Idêntica lição é a de Edmund Mezger, in verbis: "a interpretação, como averiguação de sentido é, em última instância, atividade valorada. Aqui o direito se apresenta como parte integrante da valoração humana e especialmente ética. Quando o direito, tratado num positivismo legal unilateral, perde esta conexão, se converte em algo inútil, em um joguete no poder de déspotas ambiciosos e desconsiderados. Toda interpretação deve ter consciência, portanto, de tal conexão" 39

O sentido teleológico é o que aponta à ratio legis, aos princípios fundamentais que inspiram o sistema. Segundo Marcelino Rodriguez Molinero, estes princípios são de dois tipos: "princípios ético-jurídicos que necessariamente devem fazer parte de toda ordem jurídica que pretende ser lógica e justa e princípios éticojurídicos que disciplinam cada regulamentação jurídica concreta" 40

Princípios ético-jurídicos são os princípios gerais do Direito. Estes, no nosso entender, são proposições genéricas, de ordem axiológica, provenientes das normas materiais de conteúdo objetivo do Direito Natural e, consagrados, em grande parte, implícita ou explicitamente, pelo Direito Positivo, os quais, adquirindo força cogente, passam a inspirar os institutos, os ramos e o próprio sistema. Na realidade, como relembra Esser, estes princípios estão incorporados nos Códigos, tendo força expansiva. "Todo corpus iuris, diz o jurista, conta com uma riqueza de normas muito superior às textualmente formuladas" ${ }^{41}$

37. Coing, Helmut. Obra cit., pp. 274 e ss.

38. Maurach, Reinhardt. Tratado de Derecho Penal, trad. Juan Corboda Roda, Barcelona, Ariel, 1962, v. l, pp. 107 e ss.

39. Mezger, Edmund. Derecho Penal, Parte General, trad. Conrado A. Finzi, Buenos Aires, Ed. Bibliográfica Argentina, 1958, pp. 61-62.

40. Molinero, Marcelino Rodriguez. Introducción a la Ciência del Derecho, Salamanca, Libreria Cerevantes, pp. 230-231.

41. Esser, Josef. Principio y Norma en la Elaboración Jurisprudencial del Derecho, Barcelona, Bosch, 1961, pp. 171 e ss. 
De suma importância é a questão relativa à natureza e identificação desses princípios.

No que se refere à sua natureza, participamos da concepção jusnaturalista dos princípios gerais. Del Vecchio assevera que a expressão "princípios gerais do direito" se refere aos princípios do Direito Natural. ${ }^{42}$ No mesmo sentido, ensina Alfred Verdross que o fundamento ontológico do Direito Natural consiste no "desenvolvimento dos valores da pessoa humana, concebida como imagem de Deus" No entanto, "esse princípio fundamental de proteção e respeito à dignidade da pessoa humana pode ser atualizado de diferentes formas, segundo o grau de desenvolvimento da cultura dos homens" 43

Assim sendo, os princípios que inspiram o ordenamento jurídicopositivo dizem respeito à Axiologia Jurídica. O critério de adoção dos princípios gerais do Direito assinala evidente referência aos valores que constituem o sustentáculo do Direito Positivo.

Muitos preceitos do Direito Natural se inserem no Direito Positivo. Isto ocorre quando o legislador explicitamente os consagra. Então, sem perder a sua própria categoria originária, tais princípios adquirem força cogente. Torna-se impossível mesmo a sistematização normativa sem o reconhecimento dos critérios estimativos do Direito Natural. Tais princípios passam a constituir o Direito Positivo, adquirindo valor normativo, como preconiza Josef Esser. ${ }^{44}$

Tais princípios servem de base à compreensão da norma jurídica. Aliás, assinala Betti que tais critérios de valoração imanentes ao sistema se caracterizam por "excedência de conteúdo axiológico" e graças a esta expressão constituem diretrizes e instrumentos para a interpretação.

Como se pode identificar os princípios gerais? O método preconizado pelos juristas é o da indução amplificadora, que consiste em ascender, por indução, das disposições particulares da lei a proposições axiológicas mais amplas, até alcançar a base do sistema legal.

Trata-se, in casu, de uma indução completa que vai de uma enumeração suficiente de singulares ao universal. O método é, pois, diferente da analogia, que vai do particular ao particular semelhante.

42. Del Vecchio, Giorgio. Lezione di Filosofia del Diritto, $9^{\text {a }}$ ed., Milão, Giuffrè, 1953, p. 229.

43. Verdross, Alfred. Obra cit., p. 372.

44. Esser, Josef. Obra cit., pp. 171 e ss. 
Del Vecchio ensina que a indução amplificadora é o método que possibilita aferir os princípios gerais dotados de força cogente. Por sua vez, Bobbio explica que os princípios gerais do Direito são extraídos das normas particulares, não podendo, por isso, mudar de natureza quando se ascende certos degraus. Das normas só se podem extrair normas. Logo, os princípios gerais têm caráter normativo.

5. Resolução do dilema norma-caso. Desenvolvimento do Direito: intra-legem e supra-legem.

A interpretação é a pesquisa, no contexto do ordenamento de cada instituição, do princípio axiológico que a anima, a fim de que esse mesmo princípio possibilite a compreensão do preceito aplicável à espécie ou indique a existência de normas incoerentes ou insuficientes à solução do caso. A interpretação engloba os métodos já estudados.

Mas, na hipótese de preceitos reveladores de situações de incoerência e insuficiência, são necessários métodos especiais para a resolução dos defeitos, a fim de que, ao depois, possa ser criada a norma individualizada a ser aplicada. São as operações relativas à correção das antinomias e suprimento das lacunas.

A interpretação também pode revelar uma dificuldade mais complicada: a que se refere à possível dissonância entre o texto expresso e as exigências de Justiça, hipótese em que o texto, se aplicado, conduziria a uma solução injusta.

Nestas condições, existem três problemas a serem resolvidos: o das antinomias normativas, o das lacunas e o da aplicação dos esquemas normativos que geram resultados incompatíveis com o Direito justo.

Karl Larenz diz que a solução destas dificuldades está no desenvolvimento do Direito, como "continuação da interpretação" e acrescenta que tal desenvolvimento se dá intra-legem ou supra-legem, isto é, segundo critérios imanentes à lei ou critérios superadores da lei, mas sempre "intra jus": a primeira hipótese para a correção do Direito e integração das lacunas e a segunda para a solução do problema de normas conflitantes com os ideais de Justiça. ${ }^{45}$ Isto é

45. Larenz, Karl. Metodologia de la Ciencia del Derecho, trad. de Marcelino Rodriguez Molinero, Barcelona, Ariel, 1980, parte 2, cap. V. 
possível porque a vinculação do juiz não é somente à lei, mas "à lei e ao Direito". Ambos os desenvolvimentos estão legitimados.

Isto posto, cabe-nos a apreciação dos métodos de desenvolvimento intra-legem e supra-legem, os quais, segundo Karl Larenz constituem distintos graus do mesmo procedimento hermenêutico. Antes de compor a sentença, deve o juiz criar a própria norma que servirá de base à decisão. "Quod legibus omissum est, non omittetur religione judicatium" (Papiniano).

O desenvolvimento intra-legem se destina, de início, à correção das antinomias.

Vejamos como devem ser eliminadas as antinomias. Realmente, o Direito não pode permitir o contraste entre seus preceitos. As antinomias devem ser resolvidas pelos procedimentos adequados. Carnelutti assevera que a "incoerência implica a existência de uma norma a mais e, pois, uma exuberância normativa" sendo a "purgação normativa" o processo adequado. ${ }^{46}$

Ao contrário do que ocorre com relação às lacunas, cujos critérios de solução acham-se especificados no art. $4^{\circ}$ da Lei de Introdução ao Código Civil, as antinomias devem ser resolvidas por processos lógicos que a doutrina esclarece.

As antinomias a que nos referimos são denominadas, com mais propriedade, antinomias aparentes ou solúveis. Quando as contradições não podem ser eliminadas, surgem as antinomias reais ou insolúveis. Neste caso, configura-se a lacuna de conflito, isto é, uma norma elimina a outra, de modo que o Direito permanece inacabado. As estipulações anulam-se reciprocamente. Deve-se apelar, nesta hipótese, ao suprimento das lacunas que estudaremos logo a seguir.

Duas operações são indicadas para o suprimento das antinomias: uma relativa à descoberta e outra relativa à sua eliminação.

O processo de descoberta corresponde à interpretação que deve ser realizada segundo as etapas já analisadas acima. A correção normativa evidencia o processo para a obtenção da norma a ser aplicada.

Segundo a doutrina, existem três critérios de solução: o critério cronológico, o hierárquico e o da especialidade. O critério cronológico permite resolver a contradição apresentada por duas normas sucessivas, situadas no mesmo plano da pirâmide kelseniana. Se duas normas incompatíveis se sucedem no tempo, é

46. Carnelutti, Francesco. Teoria General del Derecho, Madrid, Ed. Revista de Derecho Privado, 1941. 
válida a norma posterior. O critério da hierarquia decorre da construção gradualística do sistema. A norma que se situa no patamar superior predetermina o conteúdo e a forma de produção da norma inferior. Logo, prevalece a norma superior. O critério da especialidade diz respeito à resolução da incompatibilidade entre uma norma geral e uma especial. Esta há de prevalecer já que estabelece tratamento diferenciado para determinadas situações jurídicas, constituindo exceção à norma geral.

Diz Alberto Trabucci que "o direito comum contém normas ditadas em geral para todas as relações de um determinado tipo, enquanto que o especial forma um conjunto próprio e característico, o qual visa satisfazer particulares exigências de vida e se refere a matérias, a circunstâncias bem determinadas ou a pessoas que exercem funções ou atividades tipicas. ${ }^{47}$ Devendo-se atender ao tratamento diferenciado, a norma especial é a que prevalece.

Tais critérios, como observa Gavazzi, não são completos. Além disso, nem sempre são coerentes. ${ }^{48}$ Contudo, permitem resolver grande parte das antinomias aparentes. Se inexiste possibilidade de remoção do conflito, ocorre a antinomia real. A solução desse impasse deve ser encontrada no afastamento de ambas e na aplicação dos procedimentos que suprem as lacunas.

O desenvolvimento intra-legem também possibilita o suprimento das lacunas.

Vejamos o que vem a ser uma lacuna. Para a elaboração das normas jurídicas, o legislador parte da adoção de certo esquema de valores.

Algumas vezes deixa de prever situações que esse esquema estava a exigir, necessariamente. A falha, portanto, não é de ordem axiológica, mas decorre da própria construção. Aí está a lacuna.

Mas, não se pode falar em lacuna quando o legislador não-insere, no ordenamento jurídico, a norma justa. Lacuna não é, portanto, a carência de norma justa.

Lacuna é fenômeno que decorre da construção legislativa que, tendo em vista determinados valores de convivência e dispondo de certos meios (os processos de tipificação) não-consegue atingir situações que deveriam ser reguladas em decorrência do próprio plano adotado. Os valores consagrados, imanentes à construção, demandavam respostas a certas questões, mas estas não foram

47. Trabucci, Alberto. Istituzioni di Diritto Civile, 26“a ed., Pádua, Cedam, 1983, pp. 35-36.

48. Gavazzi, Giacomo. Elementi di Teoria di Diritto, Turim, Giappichelli, 1970. 
enfrentadas pelos preceitos normativos. O legislador deixou de inferir todas as conseqüências que a natureza lógica da construção reclamava, apresentando-se esta, assim, inacabada.

Lacuna é, na exata conceituação de Pierre Pescatore, "a omissão da lei na resolução de uma questão que devia, necessariamente, ser resolvida" ${ }^{49} \mathrm{~A}$ complementação faltante é a que provém da exigência da "teleologia imanente ao sistema" como se expressa Claus Wilhelm Canaris. ${ }^{50}$

Entendemos por lacuna a carência de preceito normativo que, em decorrência dos princípios axiológicos consagrados pela ordenação sistemática, deveria, de forma expressa e necessária, a esta pertencer.

Isto posto, indagamos: quais são os procedimentos que devem ser adotados para o preenchimento da situação de insuficiência? Como se opera o desenvolvimento do Direito intra-legem?

A solução preconizada pelo art. $4^{\circ}$ da Lei de Introdução ao Código Civil aponta três métodos: o da analogia, o do recurso aos costumes e o da aplicação dos princípios gerais do Direito. A doutrina acrescenta mais um: o da eqüidade. Mas, a eqüidade não é um recurso especial para certos casos. Ela é a Justiça do caso concreto, necessária à aplicação prudente de toda e qualquer norma jurídica, segundo lição de Recasens Siches. ${ }^{51}$ A epiqueya, segundo Aristóteles, é uma singular espécie de Justiça, porque torna possível a acomodação da lei às exigências dos casos concretos. É a régua da Lesbos que se adaptava à sinuosidade dos corpos que deviam ser medidos. A "jurisprudência da eqüidade" é exigência decorrente da própria problemática do "Direito de normas", segundo Heinrich Henkel. ${ }^{52}$ Se a eqüidade é um princípio diretivo para correção da generalidade das normas, a fortiori deve ser um critério para corrigir as situações de insuficiência.

49. Pescatore, Pierre. Obra cit., pp. 299-300.

50. Canaris, Claus Wilhelm. De la manière de constater et de combler les lacunes de la loi en Droit Allemand, in Le Problème des Lacunes, Bruxelas, 1968, p. 1.162.

51. Recasens Siches, Luis. Introducción al Estudio del Derecho, $2^{\mathrm{a}}$ ed., México, Porrua, 1972, pp. 239-246.

52. Henkel, Heinrich. Obra cit., p. 539 
A analogia é o primeiro critério para o preenchimento das lacunas. Segundo Hans Nawiasky, consiste a analogia na "aplicação de uma norma a um suposto similar ao que ela contempla, em virtude de igualdade de fundamento" 53

Existem dois casos semelhantes: o previsto e o não-previsto. $\mathrm{O}$ primeiro se resolve pela simples subsunção normativa; o segundo, por via oblíquia, porque contém relevantes elementos de semelhança aos da descrição normativa do caso previsto. Justifica-se, assim, a aplicação da mesma norma, porque os dois casos visam à realização de idênticos valores.

O método teleológico, já estudado, é uma etapa preliminar. É ele que revela serem os fins visados pela norma do caso previsto idênticos aos que decorrem da análise do caso não-previsto. É ele que indica a necessidade de se recorrer à integração normativa para a solução justa da espécie.

Por isso, o juiz deve construir a norma nova, contendo esta as condições de aplicação do caso não-previsto e o dispositivo do caso previsto, sempre vinculado a valores imanentes e latentes do ordenamento jurídico, segundo expressão de Betti.

O emprego da analogia depende dos seguintes elementos: a. uma semelhança, de caráter relevante, entre os elementos das duas situações, a prevista e a não-prevista; b. identidade de fundamento axiológico relativo à hipótese em estudo; c. transposição, por procedimentos lógicos adequados, do dispositivo referente à hipótese prevista para a não-prevista.

Delimitado o conceito, duas considerações se impõem: uma de ordem lógica; outra, de ordem epistemológica. A primeira diz respeito aos argumentos analógicos; a segunda, sobre a validade ou eficácia jurídica desses mesmos argumentos.

O argumento que convém à analogia é conhecido por "raciocínio por semelhança ou exemplo" Jacques Maritain ensina que a analogia é uma "indução parcial e imperfeita, na qual o espírito passa de um ou alguns fatos singulares (ou de uma enumeração parcial) não a uma conclusão universal, mas a outra enumeração singular ou particular, que ele infere em virtude de uma semelhança". Diz mais que se trata de "um esboço de indução que fica a meio caminho" 54

53. Nawiasky, Hans. Teoria General del Derecho, trad. Jose Zafra Valverde, Madrid, Rialp, 1962, p. 204.

54. Maritain, Jacques. Obra cit., pp.308-311. 
Os argumentos analógicos são três: a argumentação a pari, per analogiam, (ou a simili), e argumentação a fortiori, (incluindo-se nesta a argumentação a maiori ad minus, a minore ad maius) e a contrario.

Diz o professor Goffredo Telles Júnior que a argumentação a pari é "aquela em que a conclusão aceita uma asserção, pela mesma razão que a asserção anterior é aceita no antecedente"; a argumentação a fortiori é "aquela em que a conclusão aceita uma asserção, com mais razão do que a que a justificou a asserção semelhante no antecedente"; a argumentação a contrario é "aquela em que a conclusão aceita uma asserção por razão contrária à que justificou, no antecedente, a aceitação da asserção contrária" ${ }^{55} \mathrm{O}$ argumento a fortiori, já definido, se apresenta sob dupla forma: a minori ad maius e a maiori ad minus. Consiste o primeiro, segundo Kalinowski, em "inferir uma proibição mais importante a partir de uma proibição considerada menos importante"; consiste o segundo, "em se inferir de uma autorização de maior grau uma de menor grau, implicitamente contida na primeira" 56

Tais raciocínios conduzem, como deixou claro o conceito de Jacques Maritain, a uma indução imperfeita. Denotam, por isso, conseqüências prováveis. Assim sendo, sob o ponto de vista jurídico, em que deve preponderar o valor do resultado (o justo concreto), o raciocínio só pode ser aceito se atender aos princípios axiológicos que ditaram as instituições. Deve ser julgado à luz da prudência, como adverte Kalinowski.

Portanto, as considerações de ordem epistemológicas (gnoseologia da certeza) evidenciam que os mesmos raciocínios devem ser usados com as necessárias cautelas. Aqui intervém a prudência jurídica.

É o que demonstra Karl Engisch. Valendo-se de exemplo do Direito Romano, diz o jurista que tais raciocínios, embora sejam corretos sob o ponto de vista lógico, não podem ser, desde logo, usados para fins hermenêuticos. É preciso verificar, de antemão, se os mesmos conduzirão a um resultado justo. O exemplo é o que se segue. A Lei das Doze Tábuas diz que "o proprietário de um animal quadrúpede responde pelos prejuizos que o animal venha a causar" Se estes prejuízos forem causados por um bípede, qual é a responsabilidade do proprietário?

55. Telles Jr., Goffredo. Tratado da Consequiencia, $2^{\text {a }}$ ed., São Paulo, Busatsky, 1962, p. 306-308.

56. Kalinowski, Georges. Introducción a la Logica Jurídica, trad. Juan Causabon, Buenos Aires, Eudeba, 1973, pp. 170-176. 
$\mathrm{O}$ argumento a simili indica que o bípede tem certas semelhanças com o quadrúpede, sendo ambos perigosos e capazes de causar prejuízos. O argumento a contrário demonstra que o preceito válido para o quadrúpede não pode valer outros animais de características diferentes, excluídos, expressamente da disciplina normativa. Considerações de ordem axiológica levaram à admissão, no Direito Romano, do primeiro argumento, porque só este atende à finalidade imanente à instituição da responsabilidade civil. ${ }^{57}$

A argumentação por analogia conduz a uma demonstração apenas provável. Tal situação exige algumas considerações de ordem epistemológica. A indução, parcial e imperfeita, acima definida, não-conduz à certeza do silogismo porque: versa sobre o provável. A conseqüência do raciocínio não-consiste num conhecimento certo, mas, apenas, uma opinião. As proposições prováveis apóiam-se em razões apenas convincentes, não-excluindo, porém, outras, de certo peso.

Nesta ordem de idéias, forçoso é convir que o raciocínio por analogia só pode ser empregado após juizos prudenciais. É necessário atentar à sua eficácia jurídica, em cada caso, verificando-se o valor do resultado a que pode conduzir. A correção material da decisão é a que deve prevalecer. Por isso, Georges Kalinowski salienta que a interpretação está sujeita a regras lógicas e extralógicas: as primeiras dizem respeito aos argumentos analógicos já estudados; a segunda, às indicações que emanam da prudência judicial. Constitui objeto da interpretação extrair o sentido de valor que anima as normas jurídicas.

Para concluir, convém relembrar que a analogia propriamente dita é a analogia legis. Este é o processo acima estudado. A analogia juris se confunde com os princípios gerais do Direito. No raciocínio por analogia (legis), a ampliação contida na norma para o caso não-previsto é limitada e particular. Não se pode ascender a uma proposição universal pela analogia. A analogia juris leva a um princípio genérico, por ser extraída de um complexo mais amplo, isto é, do sistema. Atinge os princípios gerais do Direito. É o pensamento de Del Vecchio, que adotamos

A analogia juris não é o meio hábil para caracterizar o procedimento de integração normativa em foco. Diz respeito a outro procedimento (o dos princípios gerais do Direito) que tem pressupostos diversos.

57. Engisch, Karl. Introdução ao Pensamento Jurídico, trad. J. Baptista Machado, Lisboa, Calouste Gulbenkian, $6^{\mathrm{a}}$ ed., 1988, pp. 291 e ss. 
O costume vem a ser o segundo critério legalmente indicado para o suprimento das lacunas. Trata-se de uma forma de expressão dos preceitos normativos. Alexandre Correia e Gaetano Sciascia assim o definem: "observância geral, constante e uniforme de uma regra de conduta por parte dos membros da comunidade social, convencidos de sua correspondencia a uma necessidade jurídica" ${ }^{58}$ Como se verifica do preceito, são elementos necessários à sua configuração: um, de ordem material, elemento objetivo, externo (o corpus); e outro, de ordem psicológica, elemento subjetivo, interno (o animus). O corpus é constituído da repetição do comportamento de forma uniforme e prolongada; o animus corresponde à conviç̧ão de que a norma costumeira atende a uma necessidade de ordem jurídica.

Ao lado do jus scriptum, figura o jus non-scriptum, mas não de existir entre eles contraposição. Não pode haver concorrência entre a lei e o costume, porque o sistema é uno. Uma coisa é a formação do costume, que independe da lei; outra, sua plena eficácia, que depende da convalidação legal. O poder do costume depende da coincidência entre a sua ratio juris e a da ordem legal, como assinala Betti. A eficácia das normas costumeiras está condicionada à realização dos propósitos que decorrem da teleologia imanente ao sistema.

Pode-se divisar, a respeito, três espécies de costume: o costume secundum legem, interpretativo da lei; o costume praeter legem, integrativo da lei; e o costume contra legem, revogatório da lei. Este último por destoar da teleologia do sistema não pode prevalecer.

Para fins de integração normativa, só nos interessa o costume praeter legem. A Lei de Introdução, por reenvio expresso, possibilita essa aplicação.

Quais são as condições necessárias para sua aplicação? A norma consuetudinária deve ser submetida à interpretação, bem como a uma pesquisa complementar, relativa ao confronto da prescrição costumeira com os critérios teleológicos objetivos da ordem jurídica.

Para que a norma costumeira possa ser aplicada, é necessária a pesquisa preliminar sobre sua existência, abrangendo esta a tipicidade social e o sentido de valor que esta traduz, bem como uma pesquisa adicional desses dados à luz da teleologia imanente ao sistema. Em primeiro lugar, impõe-se a análise da

58. Correia, Alexandre e Sciascia, Gaetano. Manual de Direito Romano, São Paulo, Saraiva, 1961, v. 1, pp. 22-23. 
prova da observância, geral, prolongada e uniforme de determinados comportamentos; em segundo lugar, a pesquisa da ratio juris que essa tipicidade traduz em confronto com os valores do ordenamento jurídico. É o que ensina Emílio Betti. $^{59}$

Trata-se, in casu, de interpretação especial que se baseia em prova concreta da existência da norma mais a análise de sua compatibilidade com o estilo valorativo do sistema legal.

O costume praeter legem, assim, formulado, se destina a remediar a insuficiência do sistema normativo. Podemos defini-lo da seguinte forma: regra de conduta, supletiva das lacunas e integradora do sistema legal, derivada do uso prolongado, geral e uniforme, revestido da convicção, pela consciência comum do povo, de sua obrigatoriedade, regra cuja aplicação depende de prova das condições de sua existência e da compatibilidade com os princípios axiológicos imanentes da referida ordenação, judicialmente verificados.

Os princípios gerais do Direito constituem outro método de integração das lacunas do sistema. A pesquisa desses princípios, para fins de integração normativa, está indicada expressamente no art. $4^{\circ}$ da Lei de Introdução. Contudo, é certo que toda e qualquer tarefa interpretativa exige, necessariamente, o recurso e a invocação de um princípio geral. A interpretação é a pesquisa, no contexto sistemático de cada instituição, do princípio axiológico que a preside. Os princípios gerais do Direito se encontram subjacentes aos preceitos legais, reaparecendo por ocasião da interpretação.

O juiz, para realizar a integração, recorre a tais princípios, desde que sejam insatisfatórios os métodos anteriores.

Mas, o critério de gradação (analogia, costumes e princípios gerais do Direito) não é estritamente lógico. Todo e qualquer método conduz, invariavelmente, aos princípios gerais. Com efeito, aplicado a analogia, o juiz está, necessariamente, acolhendo um princípio geral. Por sua vez, reconhecendo o costume, o juiz está inserindo no sistema norma que se harmoniza com os esquemas valorativos legalmente consagrados.

Por fim fala-se na eqüidade como processo integrativo das lacunas. A eqüidade é, por natureza, o meio normal de integração do sistema normativo, o qual,

59. Betti, Emílio. Interpretacción de la Ley y de los Actos Juridicos, trad. de Jose Luis de los Mozos, Ed. Rev. de Derecho Privado, pp. 31 e ss. 
por sua tendência ao justo, não pode autorizar a permanência de omissões infringentes de seus objetivos éticos. Se o sistema legal é, por natureza, lacunoso, como assevera Maggiore, segue-se que ele deva ser completado e integrado por obra do juiz, a quem cabe intervir para o resguardo dos princípios estruturais das diversas instituições. Nesta hipótese, cabe ao juiz criar a norma supletória, de acordo com os princípios do Direito Natural que informam o sistema legal. Este, como já demonstramos, se baseia em valores de convivência. Tais valores possibilitam suprir as omissões de forma eqüitativa, quando falham os critérios anteriores.

A eqüidade, embora alinhada entre os processos de integração normativa desempenha, na verdade, função muito mais ampla. Não é um recurso extraordinário, e sim a maneira normal, correta e necessária de toda e qualquer interpretação judicial.

Vejamos, agora, o desenvolvimento supra-legem, ou praeterlegem, destinado a superar as dissonâncias existentes entre a norma considerada injusta relativamente ao caso sub judice. Convém lembrar que esse processo é, sempre, intra-jus, porque se encontra vinculado à teleologia imanente do sistema. Segundo a lição de Karl Larenz, trata-se de um desenvolvimento "em consonância com os princípios gerais da ordem jurídica e com a dos valores constitucionais" $\mathrm{O}$ desenvolvimento supra-legem supera o marco da regulamentação legal, mas ele ocorre intra-jus, isto é, de acordo com a teleologia imanente ao sistema. ${ }^{60}$

O método é viável porque a ordem jurídica tem amplitude maior do que a da lei. Contudo, certos pressupostos devem ser rigorosamente observados. Em primeiro lugar, o intérprete deve se guiar pelos "principios e valores que inspiram e sustentam a ordem jurídica" Em segundo lugar, deve-se manter nos "limites impostos pela ordem de valores fixada na Constituição" É o que assinala Marcelino Rodriguez Molinero. ${ }^{61}$

Quando a norma particular existe, mas sua aplicação conduz a um resultado injusto, o preceito deve ser afastado. Diz Recasens Siches que, no caso, o juiz deve optar pelos princípios gerais do Direito e resolver o impasse de acordo com os critérios valorativos que inspiram o sistema. Na hipótese, cabe a pesquisa, por indução amplificadora, dos princípios gerais do Direito que são imanentes à estrutura normativa e que compõem a teologia do sistema.

60. Larenz, Karl. Obra cit., parte 2, cap. V.

61. Molinero, Marcelino Rodriguez. Obra cit., pp. 230 e ss. 
Assim, são estes, em geral, os processos que são empregados para a resolução de todas as hipóteses de interpretação e de desenvolvimento intra-legem e supra-legem.

A observação atenta de todas as etapas dos procedimentos estudados revela que os mesmos possibilitam o adequado manejo dos esquemas legais para a solução eqüitativa dos casos concretos. É que, em todas essas situações, o juiz completa a obra do legislador, emergindo, assim, o Direito judicial de estimação.

A decisão judicial é um ato de compreensão e de vivência da decisão moral tomada pelo legislador, como adverte Helmut Coing. ${ }^{62}$ Compete ao juiz construir, mediante as valorações do sistema, as normas individualizadas das sentenças, respeitando, de um lado, a teleologia imanente do sistema e, levando em conta, por outro, os traços da situação convivencial.

A resolução da antinomia está na aplicação prudencial do Direito, como único meio para a obtenção da sentença justa. Só a prudência permite extrair da norma abstrata e genérica do ordenamento jurídico, a solução justa e adequada à singularidade do caso.

A seguinte lição de Jacques Maritain, relativamente ao ato moral, tem idêntica ressonância com referência à aplicação dos esquemas normativos: "il ne faut pas oublier que la norme universelle, dans tout acte vraiement moral a à être rendue individuelle par le mouvement d'interiorisation prudentielle que l'intègre a la poursuite singulière des fins personelles du sujet" (Neuf Leçons sur les Premières Principes de la Philosophie Morale, p. 142).

6. Aplicação prudencial do Direito. Dimensão criadora da prudência. O silogismo prudencial. Prudência e "direito de situação"

Entretanto que a aplicação do Direito exige sempre uma construção prudencial. Segundo Helmut Coing, a aplicação do Direito deve levar em conta as valorações subjacentes à ordem jurídica e o julgamento do caso deve atentar às características essenciais da situação. ${ }^{63}$ De fato, todos os procedimentos hermenêuticos estudados ao longo do presente trabalho evidenciaram que o intérprete deve transpor os objetivos éticos contidos no sistema normativo para o

62. Coing, Helmut. Obra cit., pp. 251 e ss.

63. Coing, Helmut. Obra cit., pp. 253 e ss. 
caso concreto. A resolução dos problemas específicos também demonstrou que, em todo ato interpretativo, existe uma tomada de posição axiológica, na passagem do genérico ao específico.

Esta passagem seria uma aporia se não interviesse a eqüidade. A epiqueya, segundo rigorosa conceituação de Johannes Schuster, incluída no Dicionário de Filosofia, de Walter Brugger, é a "justiça superior, acima do preceito genérico em virtude do qual é lícito ao homem agir contra a letra de uma norma juridica obrigatória pelo rigor inadequado da mesma num caso concreto, sendo, apesar disso, sua ação conforme à mente do legislador" ${ }^{64}$

O juiz é o órgão criador do Direito porque, em última análise, é ele quem realiza a eqüidade. Não a eqüidade como corretivo da lei. Mas a eqüidade que está presente em toda e qualquer problemática hermenêutica. Solução justa é a solução adequada do caso, conveniente às suas condições e apropriada às circunstâncias.

Solução justa é, nesta ordem de considerações, a solução iluminada pela prudência. Conseqüentemente, a prudência tem dimensão criadora. É dela que decorre o Direito justo e eqüitativo.

A virtude operativa da prudência dirige a ação no domínio prático. Sendo o Direito ordenado à realidade concreta, ele permanece imperfeito em sua ordem, enquanto não-determinar a conduta convivencial concreta. Possui universalidade, enquanto se refere à descrição tipológica dos direitos subjetivos e dos deveres jurídicos. Mas, em última análise, dirige-se ao singular.

É a prudência que possibilita a união do conhecimento dos princípios gerais aos dos casos concretos do agir humano. Ela se funda no entendimento e o habilita a formar o juízo do que, em cada caso, exige o Direito normativo. É a regra de razão na conduta da vida, permitindo uma ligação entre as exigências éticas e a situação. É o meio para a realização do bem e do justo numa situação de existência.

Segundo Aristóteles, a prudência é a recta ratio agibilium. É a virtude que dispõe a inteligência a discernir o que deve ser feito e o que deve ser evitado na conduta da vida. É uma virtude do intelecto prático. Conduz a realizar determinadas ações que servem de meios adequados para alcançar determinados fins. A prudência se manifesta através do conhecimento, da valoração e da decisão. Nas duas primeiras

64. Schuster, Johannes. Verbete epiqueya, Dicionário de Filosofia Walter Brugger, Herder, 1972, pp. 181-182. 
se encontra o momento cognoscitivo; na segunda, o momento diretivo. É a lição de Joseph Pieper. ${ }^{65}$

No caso da prudência jurídica, esta virtude possibilita a determinação do justo concreto, possibilitando ao juiz arquitetar e compor uma decisão coerente e dependente do sistema, sem menosprezo dos traços essenciais de que cada situação confidencial se reveste.

Tendo em vista as considerações acima referidas, algumas correntes doutrinárias têm repelido a forma estrutural silogística da sentença. Dizem que a operação judicial não pode ser reduzida a uma operação lógica, limitando-se o juiz a um simples ato de conhecimento.

Assim não-pensamos. Em primeiro lugar, o silogismo é uma forma normal do conhecimento humano e também se apresenta no conhecimento prático. Em segundo lugar, a Lógica se preocupa com o raciocínio correto, isto é, aquele que atende às regras da inferência. A preocupação relativa ao raciocínio verdadeiro, no caso, justo, é de outra ordem. A Lógica opera a partir da colocação das premissas. Ela se preocupa em saber se a conclusão pode ser necessariamente extraída das premissas. A ciência do pensamento correto é a Lógica Material.

Nada impede que o raciocínio jurídico justo, isto é, o que conduz a uma decisão eqüitativa, se manifeste estruturalmente de acordo com as regras de inferência da Lógica Formal.

Nesse mesmo sentido é a lição de Eduardo Garcia Maynez, in verbis: "o problema lógico relativo à forma ou estrutura dos raciocínios que possibilitam a aplicação de normas abstratas aos casos concretos da experiência jurídica é completamente diverso do que consiste na formulação das premissas desses raciocínios" E conclui: "analisar a estrutura de um raciocínio é questão lógica; escolher corretamente as premissas em que descansam as inferências de um julgamento de um juiz ou um advogado é, ao contrário, questão jurídica, de caráter primordial" 66

A aplicação do Direito, portanto, se manifesta de forma silogística. Cabe ao juiz formular o silogismo prudencial. O problema está na escolha certa das premissas, porque estas dependem de duas coisas: do estabelecimento do fato e da

65. Pieper, Joseph. Virtudes Fundamentais, trad. Marino e Silva e Beckert da Assunção, Lisboa, Aster, pp. 19 e ss.

66. Garcia Maynez, Eduardo. Filosofia del Derecho, $3^{\text {an }}$ ed., México, p. 198. 
eleição da norma a ser aplicada. O raciocínio depende de regras lógicas, ditadas pela Lógica Formal e regras extralógicas, ditadas pela prudência. É a lição de Kalinowski. ${ }^{67}$

Em suma: a aplicação prudencial do Direito é compatível com a sua formulação silogística. Como diz Jacques Maritain: "a Lógica Formal ensina as regras para que o raciocínio seja bem construido, abstração feita do conteúdo dessas mesmas proposições" 68

$\mathrm{O}$ raciocínio jurídico de ser formalmente bem construído e materialmente justo.

A aplicação prudencial do Direito revela ser inaceitável o "Direito de situação" ou o "Direito alternativo" Na verdade, o juiz se defronta com a lei, que prevê situações típicas, ou com a jurisprudência que apresenta soluções para casos similares, mas, nem sempre aquelas e estes coincidem com as situações conflituais específicas do julgamento. Muitas vezes, nem a lei nem a casuística trazem a adequada solução para a situação conflitual que, em sua individuação e contingência, não-coincidem, in totum, com a descrição legal ou a casuística.

Mas, não é possível apelar ao Direito de situação. Jean Dabin mostra ser impossível o existencialismo jurídico posto nestes termos. A própria noção de Direito Positivo exige a norma genérica, destacada dos fatos contingentes. A norma preestabelecida é necessária pela própria natureza do Direito. Se não fosse assim onde estaria a imperatividade? E mais: onde ficaria o caráter prospectivo da norma?

Além disso, a vinculação jurídica que se apresenta no caso sub judice reproduz as notas da bilateralidade e atributividade inerentes à conceituação normativa. Duas são as condutas que se interferem. Em qual delas estaria a "situação" a ser considerada? Impossível disjungir o caso de sua solução normativa. O caso é sempre especial. Rigorosamente falando, inexiste o precedente. Mas, o juiz tem que aplicar o preceito genérico. É para aplicá-lo e não para dispensá-lo que o juiz necessita da virtude da prudência. Não existe o preceito singular para o caso singular, mas o preceito universal para o caso singular. Só a prudência permite considerar o preceito genérico e a peculiaridade da conduta do membro da comunidade engajado numa situação de juridicidade ou de antijuridicidade, de valor ou de desvalor.

67. Kalinowski, Georges. Obra cit., pp. 170 e ss

68. Maritain, Jacques. Obra cit., pp. 26-27. 


\section{Conclusões.}

Tendo em vista as considerações expendidas ao longo do presente trabalho, podemos retraçar, em alguns enunciados, as nossas conclusões:

1. A norma jurídica é, por natureza bilateral, atributiva. Estabelece entre os membros da comunidade uma relação de reciprocidade entre os direitos subjetivos e deveres jurídicos que lhes são prospectivamente atribuídos. Deve o intérprete pesquisar o sentido axiológico que anima o preceito normativo, revelando o suum de cada um dos participantes da relação intersubjetiva.

2. Contudo, as normas juridicas estão contidas na ordem sistemática do ordenamento jurídico e se apresentam escalonadas em planos, de modo que a norma superior predetermina o conteúdo da norma inferior.

3. A interpretação vem a ser a operação que acompanha a passagem de um a outro degrau. Isto decorre das conexões lógicas e axiológicas decorrentes do sistema. A interpretação é um ato de conhecimento, de vontade e de criação normativa: de conhecimento, porque o intérprete exerce sua capacidade cognoscitiva para desvendar o texto da lei; de vontade, porque referida descoberta, revelando um marco de possibilidades, possibilita ao intérprete a escolha de uma delas para a solução do caso concreto; e de criação normativa, porque o intérprete, ao escolher uma solução, cria uma norma nova, individualizada, para a espécie. É o pensamento de Kelsen.

4. Falta, porém, a esta enumeração o essencial, a saber, o ato de valoração que propiciou a aplicação da norma superior e a criação da norma inferior. $\mathrm{O}$ ato de valoração se verifica em todas as etapas da aplicação do Direito. O intérprete, de início, conhece esquemas normativos que traduzem valores, isto é, ele descobre a "teleologia imanente ao sistema"; em seguida, escolhe uma das possibilidades, agindo através de juízos de valor, porque a escolha resulta da compreensão de um sentido de valor imanente à conduta e legalmente previsto; e, finalmente, ao criar a norma individualizada, atualiza e traduz, para o caso concreto, as valorações imanentes ao sistema.

5. O intérprete assume sempre posição axiológica. A interpretação é, assim, um ato de conhecimento, um ato de vontade e um ato de criação normativa, em que sobressai, em todas as etapas, a valoração. É o que preconiza a "jurisprudência dos valores" 
6. A via para a resolução da antinomia entre a norma e o caso está na construção prudencial da sentença. A tarefa do juiz se exerce no plano do concreto, nascendo sua decisão de uma luz normativa.

7. A prudência tem assento no entendimento e capacita o juiz a formar um juízo a respeito do que, em cada caso, exige a conduta humana em sociedade. A ordem jurídica, erigida segundo configuração típica, prescreve o dever e atribui o Direito para a generalidade dos casos. A prudência permite ao juiz traduzir as exigências axiológicas, contidas nos mandamentos legais, para os casos específicos.

8. A resultante desse processo de construção prudencial é a eqüidade, ou Justiça do caso concreto. Decisão eqüitativa é a que, na aplicação dos esquemas normativos aos casos concretos, na correção das antinomias e na integração das lacunas, considera as notas distintivas das situações conflituais, decorrente da "natureza da coisa". que foram desprezadas no processo de tipificação normativa.

9. O ciclo vital do Direito é, como vimos, um contínuo processo de interpretação e desenvolvimento intra-legem e supra-legem, que se realiza pelo juízo prudencial. Através deste, esplende o Direito justo.

São Paulo, setembro de 1998. 